\title{
On the abundance and source contributions of dicarboxylic acids in size-resolved aerosol particles at continental sites in central Europe
}

\author{
D. van Pinxteren ${ }^{1}$, C. Neusüß ${ }^{2}$, and H. Herrmann ${ }^{1}$ \\ ${ }^{1}$ Leibniz-Institut für Troposphärenforschung (TROPOS), Permoserstr. 15, 04318 Leipzig, Germany \\ ${ }^{2}$ Hochschule Aalen, Beethovenstr. 1, 73430 Aalen, Germany \\ Correspondence to: H. Herrmann (herrmann@ tropos.de)
}

Received: 28 November 2013 - Published in Atmos. Chem. Phys. Discuss.: 9 December 2013

Revised: 12 March 2014 - Accepted: 18 March 2014 - Published: 17 April 2014

\begin{abstract}
Dicarboxylic acids (DCAs) are among the most abundant organic compounds observed in atmospheric aerosol particles and have been extensively studied at many places around the world. The importance of the various primary sources and secondary formation pathways discussed in the literature is often difficult to assess from field studies, though. In the present study, a large data set of size-resolved DCA concentrations from several inland sites in Germany is combined with results from a recently developed approach of statistical back-trajectory analysis and additional data. Principal component analysis is then used to reveal the most important factors governing the abundance of DCAs in different particle size ranges. The two most important sources revealed are (i) photochemical formation during intense radiation days in polluted air masses, likely occurring in the gas phase on short timescales (gasSOA), and (ii) secondary reactions in anthropogenically influenced air masses, likely occurring in the aqueous phase on longer timescales (aqSOA). While the first source strongly impacts DCA concentrations mainly in small and large particles, the second one enhances accumulation mode DCAs and is responsible for the bulk of the observed concentrations. Primary sources were found to be minor (sea salt, soil resuspension) or non-existent (biomass burning, traffic). The results can be regarded as representative for typical central European continental conditions.
\end{abstract}

\section{Introduction}

Low-molecular-weight dicarboxylic acids (LMW-DCAs) are arguably the most abundant compound group typically identified in atmospheric organic aerosol particles. As such they have a strong impact on the properties of organic particles and can play a role in the hygroscopic growth of particles (Choi and Chan, 2002; Prenni et al., 2003), the activation of cloud condensation nuclei (Pradeep Kumar et al., 2003; Booth et al., 2009), and ice formation (Zobrist et al., 2006). Furthermore, they often serve as tracers for the oxidative processing of water-soluble organic aerosol in the atmosphere (Sorooshian et al., 2010; Ervens et al., 2011).

A variety of both primary and secondary sources of LMWDCAs have been proposed in the literature. Among the primary ones are the rather minor sources of cigarette smoke (Rogge et al., 1994) and meat charbroiling emissions (Rogge et al., 1991), as well as the potentially more relevant one of fossil fuel combustion (Kawamura and Kaplan, 1987; Fraser et al., 1998). Evidence for the latter one is conflicting, though, with more recent studies neglecting a contribution of traffic to LMW-DCA concentrations in the atmosphere (Rogge et al., 1993a; Huang and Yu, 2007; Stone et al., 2010). DCAs were observed in high concentrations in biomass burning plumes (Jaffrezo et al., 1998; Narukawa et al., 1999; Graham et al., 2002; Gao et al., 2003; Allen et al., 2004; Falkovich et al., 2005; Kundu et al., 2010), although it is unclear to what extent they are directly emitted (Jaffrezo et al., 1998) and/or formed during the processing of the plume (Gao et al., 2003; Allen et al., 2004). In marine-influenced air masses, direct emission of DCAs associated with sea salt particles can be a primary source (Matsumoto et al., 1998), as sea water has been shown to contain non-negligible concentrations of DCAs (Tedetti et al., 2006).

In general, secondary formation from precursor gases is believed to be a more important source of LMW-DCAs in the atmosphere (Rogge et al., 1993b; Röhrl and Lammel, 
2000; Kleefeld et al., 2002; Yao et al., 2002; Wang and Shooter, 2004; Huang et al., 2005). In field studies, increasing concentrations of organic acids are often observed with increasing age of anthropogenic emission plumes (Satsumabayashi et al., 1990; Sorooshian et al., 2006; van Pinxteren et al., 2009; Veres et al., 2011). In smog chamber studies, LMW-DCAs have been observed as reaction products from anthropogenic precursors such as aromatic compounds (Fisseha et al., 2004; Sato et al., 2007; Sorooshian et al., 2007; Borras and Tortajada-Genaro, 2012) or cyclic alkenes (Hatakeyama et al., 1985, 1987; Kalberer et al., 2000; Gao et al., 2004; Hamilton et al., 2006) as well as from complex compound mixtures such as diesel exhaust (Samy and Zielinska, 2010). Biogenic precursors have been postulated to significantly contribute to LMW-DCA concentrations as well (Lim et al., 2005; Carlton et al., 2006; Ervens et al., 2008). In fact, a recent global 3-D modelling study suggested isoprene to be by far the most important precursor of oxalic acid in the atmosphere $(70 \%)$, with anthropogenic precursors contributing only about $21 \%$ on a global scale (Myriokefalitakis et al., 2011). It was also shown, however, that the model significantly underpredicted observed oxalic acid concentrations especially in urban areas. In the marine atmosphere, LMW-DCAs were proposed to be related to the degradation of longer-chain DCAs, produced from the oxidation of fatty acids (Kawamura et al., 1996b; Turekian et al., 2003; Legrand et al., 2007; Miyazaki et al., 2010), heterogeneous bromine chemistry (Narukawa et al., 2003a; Kawamura et al., 2005), acetylene and ethene oxidation (Warneck, 2003) and the oxidation of glyoxal and/or glyoxylic acid (Narukawa et al., 2003a; Miyazaki et al., 2010; Rinaldi et al., 2011). In comparison to continental source strengths, however, evidence from field studies suggests such marine sources to be less important (Kawamura and Usukura, 1993; Matsumoto et al., 1998; Kerminen et al., 1999; Neusüß et al., 2000; Röhrl and Lammel, 2001; Kleefeld et al., 2002; Bardouki et al., 2003; Mochida et al., 2003a; Narukawa et al., 2003b; Agarwal et al., 2010).

The large variety of secondary sources in diverse atmospheric regimes is a direct result of LMW-DCAs being lategeneration products in the oxidation pathways of primary gaseous precursors. In field studies, it is therefore often difficult to evaluate the contribution of the different sources and formation pathways to the observed concentrations. The aim of the present study was to elucidate the factors governing the abundance of LMW-DCAs at typical European continental sites. Size-resolved concentration data from several campaigns were compiled to ensure robust results from a statistical source apportionment approach (principal component analysis, PCA). An attempt was made to discriminate impacts from natural vegetation versus anthropogenic emissions on the formation of LMW-DCAs by including the results of advanced back-trajectory analysis and further data into the PCA.
Some of the data used in this study have already been published within the context of their respective campaigns (Neusüß et al., 2002; Plewka et al., 2004; Gnauk et al., 2005; Müller et al., 2005; Brüggemann et al., 2009). This refers mainly to inorganic ions and organic/elemental carbon $(\mathrm{OC} / \mathrm{EC})$ concentrations, which are used as indicators for certain sources in the source apportionment. The DCA data used in this study have not been published before, with the exception of 8 out of 20 samples from Melpitz (Plewka et al., 2004) and 3 out of 10 samples from Goldlauter (Müller et al., 2005; van Pinxteren et al., 2005).

\section{Materials and methods}

\subsection{Sampling}

Particle sampling was performed within several field campaigns at different locations in Germany between 1997 and 2005. They include the rural sites Melpitz, $45 \mathrm{~km}$ northeast of Leipzig $\left(51^{\circ} 32^{\prime} \mathrm{N}, 12^{\circ} 55^{\prime} \mathrm{E}\right.$, TROPOS research site, 20 samples in October-November 1997, sampling time $8-27 \mathrm{~h} \mathrm{sample}^{-1}$ ) and Falkenberg, $50 \mathrm{~km}$ southeast of Berlin $\left(52^{\circ} 10^{\prime} \mathrm{N}, 14^{\circ} 7^{\prime} \mathrm{E}\right.$, research site of German weather service, 23 samples in July-August 1998, 7$23 \mathrm{~h} \mathrm{sample}^{-1}$ ), the rural site Goldlauter in the Thuringian forest area close to Mt. Schmücke $\left(50^{\circ} 38^{\prime} \mathrm{N}, 10^{\circ} 45^{\prime} \mathrm{E}\right.$, 10 samples in October 2001 and October 2002, 5$16 \mathrm{hsample}^{-1}$ ), an urban background site in Leipzig $\left(51^{\circ} 21^{\prime} \mathrm{N}, 12^{\circ} 26^{\prime} \mathrm{E}\right.$, TROPOS institute, 30 samples in July 2003-August 2005, $24 \mathrm{hsample}^{-1}$ ) and a trafficimpacted site in Dresden $\left(51^{\circ} 4^{\prime} \mathrm{N}, 13^{\circ} 44^{\prime} \mathrm{E}\right.$, close to Dresden-Neustadt train station, 12 samples in September 2003-August 2004, $24 \mathrm{~h} \mathrm{sample}^{-1}$ ).

Size-resolved particle sampling was done at all sites using five-stage Berner impactors (Hauke, Austria) with 50\% cut-offs at $0.05,0.14,0.42,1.2,3.5$, and $10 \mu \mathrm{m}$ aerodynamic diameter $\left(D_{\mathrm{p}}\right)$ and a flow rate of $75 \mathrm{~L} \mathrm{~min}^{-1}$. The impactors were equipped with aluminium foils as impaction substrates, which were heated at $350^{\circ} \mathrm{C}$ for at least $2 \mathrm{~h}$ to reduce blank levels prior to sampling. During some campaigns, a second impactor was run in parallel and equipped with Tedlar ${ }^{\circledR}$ foils which were cleaned with $5 \%$ aqueous hydrogen peroxide solution. Sampling durations varied between a few hours and 1 day (typically 12 or $24 \mathrm{~h}$ ), depending on the aims of the respective campaign. Directly after sampling, the impaction substrates were stored at $-20^{\circ} \mathrm{C}$ until analysis, which was usually performed within about a year from the time of sampling.

Low-pressure impactors can suffer from sampling artefacts such as evaporation of semi-volatiles from the lowest stages or particle bounce-off. To reduce particle bounce, RHcontrolled sampling was performed during some of the campaigns (Melpitz, Falkenberg, Goldlauter) by installing the impactor downstream of a bundle of $73 / 4$ in stainless steel 
tubes $(1.5 \mathrm{~m}$ length), which were temperature controlled to keep the RH of the sampling air at approx. $60 \pm 10 \%$. Inlet heights were between approx. 4 and $20 \mathrm{~m}$ above ground for the different campaigns.

\subsection{Measurements}

Total particle mass was determined by weighing the impaction substrates before and after sampling on a UMT-2 microbalance (Mettler-Toledo, Switzerland) with a reading precision of $0.1 \mu \mathrm{g}$ and a standard deviation of ca. $1 \%$. For RH equilibration, the substrates were stored in a closed box at constant temperature $\left(20 \pm 2{ }^{\circ} \mathrm{C}\right)$ and $\mathrm{RH}(55 \pm 5 \%)$ for usually $48 \mathrm{~h}$ (at least $12 \mathrm{~h}$ ). A fraction of the Tedlar ${ }^{\circledR}$ foil substrate (or aluminium substrate where only one impactor was run) was extracted in 1-2 $\mathrm{mL}$ deionized water by ultrasonication and shaking, while a fraction of the aluminium substrate was used for the determination of organic and elemental carbon (OC/EC).

The aqueous particle extracts were analysed for inorganic cations by capillary electrophoresis (CE) or ion chromatography (IC), while inorganic anions as well as the DCA were always determined by CE. Reproducibility of the CE method for DCA determination is in the range of $5-10 \%$. More details of the respective methods can be found elsewhere (Neusüß et al., 2000; Brüggemann and Rolle, 1998). The applied extraction and analysis method determines the sum of both the dissociated and free acid form of a respective DCA in the particles. To differentiate between the two forms, parallel extractions in organic solvents together with an appropriate analysis method would be required (Yang and $\mathrm{Yu}$, 2008).

OC/EC determination was done by a two-step thermographic method using a C-mat 5500 carbon analyser (Ströhlein, Germany). The temperature for OC volatilization under nitrogen was $590^{\circ} \mathrm{C}$ during the early campaigns (Melpitz and Falkenberg), while for all other samples $650^{\circ} \mathrm{C}$ was used. EC was determined at $650^{\circ} \mathrm{C}$ under oxygen. More details of the method are given elsewhere (Neusüß et al., 2000; Gnauk et al., 2008).

Mixing ratios of the trace gases ozone $\left(\mathrm{O}_{3}\right)$, nitrogen monoxide (NO), nitrogen dioxide $\left(\mathrm{NO}_{2}\right)$, sulfur dioxide $\left(\mathrm{SO}_{2}\right)$, and carbon monoxide $(\mathrm{CO})$ were measured at all sites except Falkenberg using commercial standard trace gas monitors from different manufacturers using $\mathrm{UV}$ absorption $\left(\mathrm{O}_{3}\right)$, UV fluorescence $\left(\mathrm{SO}_{2}\right)$ and chemiluminescence $\left(\mathrm{NO}_{\mathrm{x}}\right)$. The gas monitors were calibrated on a regular basis. Mixing ratios at the different sites are summarized in Fig. S1 of the Supplement. The data were averaged within the sampling intervals and used in the source apportionment approach to reflect local pollution conditions.

\subsection{Back-trajectory analysis}

In this study, a method of back-trajectory calculation and GIS analysis to obtain proxy parameters for the impacts of several land cover classes on the sampled air masses has been applied to the data set of samples from the various campaigns. The method is described in full detail by van Pinxteren et al. (2010) and will only briefly be outlined here. $96 \mathrm{~h}$ back trajectories were calculated using HYSPLIT v4.9 (Draxler and Hess, 1998) with input fields ( $1^{\circ}$ resolution) obtained from the FNL archive at NOAA's Air Resource Laboratory (http://ready.arl.noaa.gov/archives.php). The model was run in the ensemble mode with a starting height of $500 \mathrm{~m}$ above ground level and offsets of one meteorological grid point in the horizontal dimension and 0.01 sigma units (ca. $250 \mathrm{~m}$ ) in the vertical dimension, yielding an ensemble of 27 trajectories for all possible offsets in the $x-, y$-, and $z$-dimension for a given starting time. Trajectory ensembles were calculated for every full hour during a sampling interval and intersected with land cover data from the Global Land Cover 2000 project of the European Commission Joint Research Centre (GLC2000 database, http://bioval.jrc.ec.europa.eu/products/ glc2000/glc2000.php) within a database system with GIS functionality (PostgreSQL 9.1 + PostGIS 2.0). The outcome is a dimensionless residence time index (RTI), which - on a relative scale between 0 and 1 - reflects the (weighted) time the sampled air masses have resided above certain land cover categories (water, natural vegetation, agricultural lands, bare areas and urban areas). The land cover classes were obtained by reclassifying the original 22 classes of the GLC2000 data set into the broader categories as given by van Pinxteren et al. (2010). Given that emissions from a given area will be strongly influenced by its land use (e.g. biogenic emissions from areas with natural vegetation, anthropogenic emissions from urban areas), the index can be regarded as a measure for potential impacts of such typical emissions from the different land cover categories to the sampled air mass during their transport to the receptor site. The residence time index is calculated in a time-weighted manner to account for a decreasing impact of areas far away from the receptor site (i.e. backward in trajectory time).

In a similar way, the meteorological output of HYSPLIT can be averaged in a weighted manner "along the trajectories" to yield a proxy for the solar flux during the past 4 days of the sampled air mass. Additionally, the HYSPLIT solar flux as well as the HYSPLIT mixing layer depth (modelled from the input meteorological fields) can be averaged at the location of the receptor site over a given sampling interval and the mean length of the trajectories during a sampling interval can be calculated. These parameters proved helpful in a previous application of the method (van Pinxteren et al., 2010) and are used in the present source apportionment study as well. 


\subsection{Principal component analysis}

PCA was performed on the data set of particulate concentrations, trace gas mixing ratios and trajectory parameters using the open source statistical software package R (http: //www.r-project.org). All concentration data (both particulate and gas data) as well as the two solar flux and the mixing height variables were $\log 10$-transformed to reduce the skewness in the variables. The skewness results from the approximate lognormal distribution of these variables and can potentially distort the results of a PCA. After log transformation, the data was mean-centred, scaled to unit variance and the correlation matrix was used for calculation of the principal components, which is necessary if variables on very different scales are to be used. As PCA requires a complete set of data, concentrations below the detection limit were set to half the detection limit, while missing data (e.g. due to instrumental problems or samples not analysed for the full suite of compounds) was replaced by the mean value of the respective parameter. It has to be noted that during the Melpitz campaign only a fraction of the samples (6 out of 20) were analysed for the full suite of DCAs, while oxalate was analysed from all of these samples. By replacing the missing data with their mean values they are set to the non-informative point at the origin of the mean-centred data and thus do not influence the outcome of the PCA. The number of factors to extract was defined by examining the scree plot of eigenvalues vs. number of PCs (Cattell, 1966) and by comparing the magnitudes of the obtained eigenvalues with those obtained from a random data matrix of the same size as the original (so-called parallel analysis, Horn, 1965). Varimax rotation was applied to the extracted principal components to result in rotated components with easier-to-interpret component loadings.

\section{Results and discussion}

\section{1 $\mathrm{PM}_{10}$ concentrations and size distributions of DCAs}

In Table 1 the concentrations of DCAs obtained in this work are summarized. Literature data from comparable European rural and urban sites are given for comparison in Table 1 . Generally, the mean DCA concentrations obtained in this study do not differ by more than a factor of about 2 between the five different sites. The urban sites do not necessarily show higher concentrations than the rural sites. Highest concentrations are always observed for oxalic followed by malonic acid. Succinic, glutaric (including two unresolved isomers, Neusüß et al., 2000), and malic acid often show comparable concentration ranges, with the exception of the summertime Falkenberg data, where glutaric and malic acid were considerably higher than succinic acid. Tartronic and tartaric acid are observed at rather low concentrations of only a few $n g \mathrm{~m}^{-3}$, if at all. A notable exception is again the Falken- berg data, where tartronic acid was observed at rather high concentrations.

Compared to the literature data, this work's DCA concentrations at urban sites usually agree within a factor of 2 with similar sites in Europe. Oxalic acid determined by Röhrl and Lammel (2001) during summer in Leipzig and Eichstädt somewhat exceeds the concentration observed at the other sites, which might be due to the sampling of total suspended matter (TSP) and/or - as indicated by the authors - possible positive sampling artefacts for oxalic acid. Concentrations at rural sites agree to a similar extent, with the exceptions of rather high TSP oxalic and malonic acid in Falkenberg (Röhrl and Lammel, 2001) and $\mathrm{PM}_{2.5}$ oxalic acid at K-puszta in the central plain of Hungary (Legrand et al., 2007). Unusually low concentrations of C3-C5 DCAs were recently reported for a rural site in Sweden (Hyder et al., 2012), possibly related to the choice of extraction solvent and/or derivatization agent for a gas chromatography/mass spectrometry (GC/MS) analysis applied in this study. Yang and Yu (2008) demonstrated that the combination of solvent extraction and trimethylsilylation GC/MS recovers only a fraction of total malonic acid (including malonate) concentrations in $\mathrm{PM}_{2.5}$ samples, while - as reported by Hyder et al. (2012) as well oxalic acid was not detected at all.

The size distributions of DCAs are given in Fig. 1 as averages over all sites. Highest concentrations for all DCAs were observed in accumulation mode particles $\left(D_{\mathrm{p}}=0.14\right.$ $1.2 \mu \mathrm{m})$ with significantly lower concentrations in ultrafine $\left(D_{\mathrm{p}}=0.05-0.14 \mu \mathrm{m}\right)$ and coarse $\left(D_{\mathrm{p}}=1.2-10 \mu \mathrm{m}\right)$ particles. Such size distributions are typical for European continental DCA measurements and have been observed in similar ways before (Mészáros et al., 1997; Kerminen et al., 2000; Müller et al., 2005; Legrand et al., 2007).

\subsection{Back-trajectory analysis}

The residence time indices as main results from the statistical back-trajectory analysis are shown in Fig. 2. As expected from the location of the sites (in-land continental), the sampled air masses had higher (time-weighted) residence times from the two main continental land cover classes of agriculture and natural vegetation as compared to the residence time above marine areas (water). Urban areas make up only a tiny fraction of continental surface area, which is why the values of this index are much smaller. The indices show a large variability, indicating that very different air masses were sampled in the various campaigns. Further output parameters from the back-trajectory analysis as described above are given in Fig. 2 as well. In agreement with the campaign season, solar flux and mixing depth were quite different at the different sites with higher values for the Falkenberg summer measurements, lower ones for the autumn campaigns in Melpitz and Goldlauter and highly variable values for the year-round measurements in Dresden and Leipzig. 
Table 1. Concentrations of DCAs determined in this work and literature data from comparable European rural and urban sites. All data given in $\mathrm{ng} \mathrm{m}^{-3}$ as mean \pm standard deviation (min-max). For Melpitz, Falkenberg and Goldlauter data mean and standard deviation were calculated in a weighted manner to account for the variable sampling times applied at these sites.

\begin{tabular}{|c|c|c|c|c|c|c|c|c|c|c|c|}
\hline Site & Season & \# & Size & Oxalate & Malonate & Succinate & Glutarate & Tartronate & Malate & Tartrate & Ref. \\
\hline \multicolumn{12}{|l|}{ Urban sites } \\
\hline Leipzig & Summer/winter & 30 & $\mathrm{PM}_{10}$ & $\begin{array}{r}82 \pm 52 \\
(10-180)\end{array}$ & $\begin{array}{l}31 \pm 23 \\
\text { (bdl-72) }\end{array}$ & $\begin{array}{c}16 \pm 12 \\
\text { (bdl-60) }\end{array}$ & $\begin{array}{r}21 \pm 20^{\mathrm{a}} \\
\text { (bdl-86) }\end{array}$ & $\begin{array}{r}4 \pm 5 \\
\text { (bdl-22) }\end{array}$ & $\begin{array}{c}17 \pm 19 \\
\text { (bdl-85) }\end{array}$ & $\begin{array}{l}4 \pm 7 \\
\text { (bdl-35) }\end{array}$ & This work \\
\hline Dresden & Year-round & 12 & $\mathrm{PM}_{10}$ & $\begin{array}{r}58 \pm 40 \\
(11-135)\end{array}$ & $\begin{array}{r}19 \pm 16 \\
(1-46)\end{array}$ & $\begin{array}{r}13 \pm 10 \\
(2-36)\end{array}$ & $\begin{array}{r}12 \pm 11^{\mathrm{a}} \\
\text { (bdl-29) }\end{array}$ & $\begin{array}{r}3 \pm 3 \\
\text { (bdl-9) }\end{array}$ & $\begin{array}{c}10 \pm 12 \\
\text { (bdl-40) }\end{array}$ & $\begin{array}{l}1 \pm 1 \\
\text { (bdl-3) }\end{array}$ & This work \\
\hline Veszprém, HU & Summer/winter & 17 & $\mathrm{PM}_{16}$ & $105 / 129^{\mathrm{b}}$ & $25 / 30^{\mathrm{b}}$ & $27 / 33^{\mathrm{b}}$ & & & & & (Mészáros et al., 1997) \\
\hline Helsinki, FI & Year-round & 50 & $\mathrm{PM}_{2.3}$ & $100^{\mathrm{c}}$ & $10^{\mathrm{c}}$ & $12^{\mathrm{c}}$ & & & & & (Kerminen et al., 2000) \\
\hline Eichstädt, DE & Summer & 22 & TSP & 251 & 56 & 18 & 10 & & & & (Röhrl and Lammel, 2001) \\
\hline Leipzig, DE & Summer & 24 & TSP & 229 & 66 & 35 & 30 & & & & (Röhrl and Lammel, 2001) \\
\hline Eichstädt, Leipzig, DE & Summer & na & TSP & & & 30 & & & 54 & 6.7 & (Röhrl and Lammel, 2002) \\
\hline Vienna, AT & Winter & 5 & TSP & $86^{\mathrm{d}}$ & $26^{\mathrm{d}}$ & $42^{\mathrm{d}}$ & $9^{d}$ & & & & (Limbeck et al., 2005) \\
\hline Zurich, $\mathrm{CH}$ & Summer/winter & na & $\mathrm{PM}_{10}$ & $135 / 104^{b}$ & $29 / 13^{b}$ & $10 / 8^{b}$ & & & $21 / 11^{\mathrm{b}}$ & $2 / 1^{\mathrm{b}}$ & (Fisseha et al., 2006) \\
\hline Oporto, PT & Summer/winter & na & $\mathrm{PM}_{10}$ & & $\mathrm{na} / 4^{\mathrm{c}}$ & $11 / 15^{\mathrm{c}}$ & $3 / 10^{\mathrm{c}}$ & & & & (Oliveira et al., 2007) \\
\hline Copenhagen, DK & Summer/winter & na & $\mathrm{PM}_{10}$ & & $0.5 / 1^{\mathrm{c}}$ & $18 / 12^{\mathrm{c}}$ & $8 / 12^{\mathrm{c}}$ & & & & (Oliveira et al., 2007) \\
\hline Jülich, DE & Summer & 6 & $\mathrm{PM}_{2.5}$ & & & 8.1 & & & 39 & & (Kourtchev et al., 2008) \\
\hline Brasschaat, BE & Summer & 71 & $\mathrm{PM}_{2.5}$ & $75^{\mathrm{e}}$ & $49^{\mathrm{e}}$ & $11^{\mathrm{e}}$ & $4.7^{\mathrm{e}}$ & & & & (Gómez-Gonzàlez et al., 2012) \\
\hline \multicolumn{12}{|l|}{ Rural sites } \\
\hline Melpitz & Autumn & 20 & $\mathrm{PM}_{10}$ & $\begin{array}{r}52 \pm 26 \\
(18-138)\end{array}$ & $\begin{array}{r}22 \pm 16 \\
(3-46)\end{array}$ & $\begin{array}{l}19 \pm 6 \\
(8-27)\end{array}$ & $\begin{array}{r}16 \pm 11^{\mathrm{a}} \\
(5-31)\end{array}$ & $\begin{array}{r}4 \pm 5 \\
(0-11)\end{array}$ & $\begin{array}{l}12 \pm 8 \\
(6-26)\end{array}$ & bdl & This work \\
\hline Falkenberg & Summer & 23 & $\mathrm{PM}_{10}$ & $\begin{array}{r}80 \pm 41 \\
(15-209)\end{array}$ & $\begin{array}{r}39 \pm 20 \\
(7-64)\end{array}$ & $\begin{array}{l}11 \pm 8 \\
(1-27)\end{array}$ & $\begin{array}{r}28 \pm 20^{\mathrm{a}} \\
(3-63)\end{array}$ & $\begin{array}{r}14 \pm 13 \\
(1-38)\end{array}$ & $\begin{array}{r}31 \pm 22 \\
(4-70)\end{array}$ & bdl & This work \\
\hline Goldlauter & Autumn & 10 & $\mathrm{PM}_{10}$ & $\begin{array}{r}36 \pm 23 \\
(16-114)\end{array}$ & $\begin{array}{r}18 \pm 16 \\
(5-67)\end{array}$ & $\begin{array}{r}12 \pm 11 \\
(3-45)\end{array}$ & $\begin{array}{r}10 \pm 11^{\mathrm{a}} \\
(\mathrm{bdl}-35)\end{array}$ & $\begin{array}{r}2 \pm 2 \\
\text { (bdl-7) }\end{array}$ & $\begin{array}{l}10 \pm 7 \\
(3-32)\end{array}$ & $\begin{array}{l}2 \pm 2 \\
\text { (bdl-6) }\end{array}$ & This work \\
\hline Merseburg, DE & Winter & 22 & TSP & 57 & 4.8 & 4.2 & & & & & (Röhrl and Lammel, 2001) \\
\hline Falkenberg, DE & Summer & 17 & TSP & 343 & 64 & 25 & 21 & & & & (Röhrl and Lammel, 2001) \\
\hline 3 rural sites, DE & Summer/winter & na & TSP & & & 14 & & & 34 & 4 & (Röhrl and Lammel, 2002) \\
\hline K-puszta, HU & Summer & 63 & $\mathrm{PM}_{2}$ & & & & & & $38^{\mathrm{e}}$ & & (Ion et al., 2005) \\
\hline K-puszta, HU & Summer/winter & na & $\mathrm{PM}_{2.5}$ & $264 / 300^{\mathrm{b}}$ & $29 / 28^{b}$ & $21 / 37^{b}$ & $19 / 21^{b}$ & & $37 / 19^{b}$ & $6 / 4^{b}$ & (Legrand et al., 2007) \\
\hline K-puszta, HU & Summer & 63 & $\mathrm{PM}_{2.5}$ & 189 & & 15 & 10 & & 40 & & (Kourtchev et al., 2009) \\
\hline Hyytiälä, FI & Summer & 51 & $\mathrm{PM}_{2.5}$ & $104^{\mathrm{e}}$ & $20^{\mathrm{e}}$ & $13^{\mathrm{e}}$ & $7^{\mathrm{e}}$ & & & & (Maenhaut et al., 2011) \\
\hline Po Valley, IT & Spring & 23 & $\mathrm{PM}_{1}$ & $100^{\mathrm{c}}$ & $15^{\mathrm{c}}$ & $8^{c}$ & & & $12^{\mathrm{c}}$ & & (Saarikoski et al., 2012) \\
\hline Vavihill, SE & Year-round & 35 & $\mathrm{PM}_{10}$ & & $1.6 \pm 0.5$ & $3.5 \pm 2.4$ & $1.8 \pm 0.8$ & & & & (Hyder et al., 2012) \\
\hline
\end{tabular}

\subsection{Source apportionment}

To assess the latent factors controlling the abundance of DCAs in different particle sizes, PCA was performed on the data set of size-resolved DCA concentrations. The following further particle constituents were included in the analysis in order to aid the interpretation of the resolved principal components: EC (primary, anthropogenic combustion or biomass burning), OC (both primary and secondary, both anthropogenic and biogenic), sulfate (mainly secondary, anthropogenic combustion), potassium (primary, biomass burning), sodium (primary, sea salt and/or soil) and calcium (primary, dust/soil). Due to missing concentration data for sodium and calcium on the smallest particles (impactor stages 1 and 2, all data below detection limit), concentrations from impactor stages 3-5 only were included for these species. Additionally, trace gas mixing ratios of $\mathrm{NO}_{\mathrm{x}}, \mathrm{CO}$ and $\mathrm{SO}_{2}$ (anthropogenic combustion) and $\mathrm{O}_{3}$ (photochemically formed) were included. All the back-trajectory parameters were included as well with the exception of the residence time indices for bare areas (negligible values for sampled air masses) and water (simply anti-correlated to the continental indices).

In PCA, the number of PCs to extract is a critical (and to some extent subjective) decision which can strongly affect the interpretability of the result. Many different procedures exist to aid this decision (Jolliffe, 2002). One of the most common ones is the scree plot of successive eigenvalues for all calculated PCs, which is shown in Fig. 3. As can be seen, the rate of decline is fast for the first seven PCs and then clearly levels off. The "elbow" of the plot (i.e. PC 7) is often considered to indicate the number of components to extract (Jolliffe, 2002). On the other hand, the eigenvalue of PC 7 is already significantly lower than that obtained from a random matrix of univariate normal data ("simulated data" in Fig. 3) and from random samples (randomized across rows) of the original data ("resampled data" in Fig. 3). Thus, in the final solution the first six PCs were chosen to be subjected to Varimax rotation. The "correctness" of the six-factor solution was, however, verified by varying the number of extracted PCs between six and seven, as will be discussed below. In Table 2 the loadings of the variables on the six rotated 


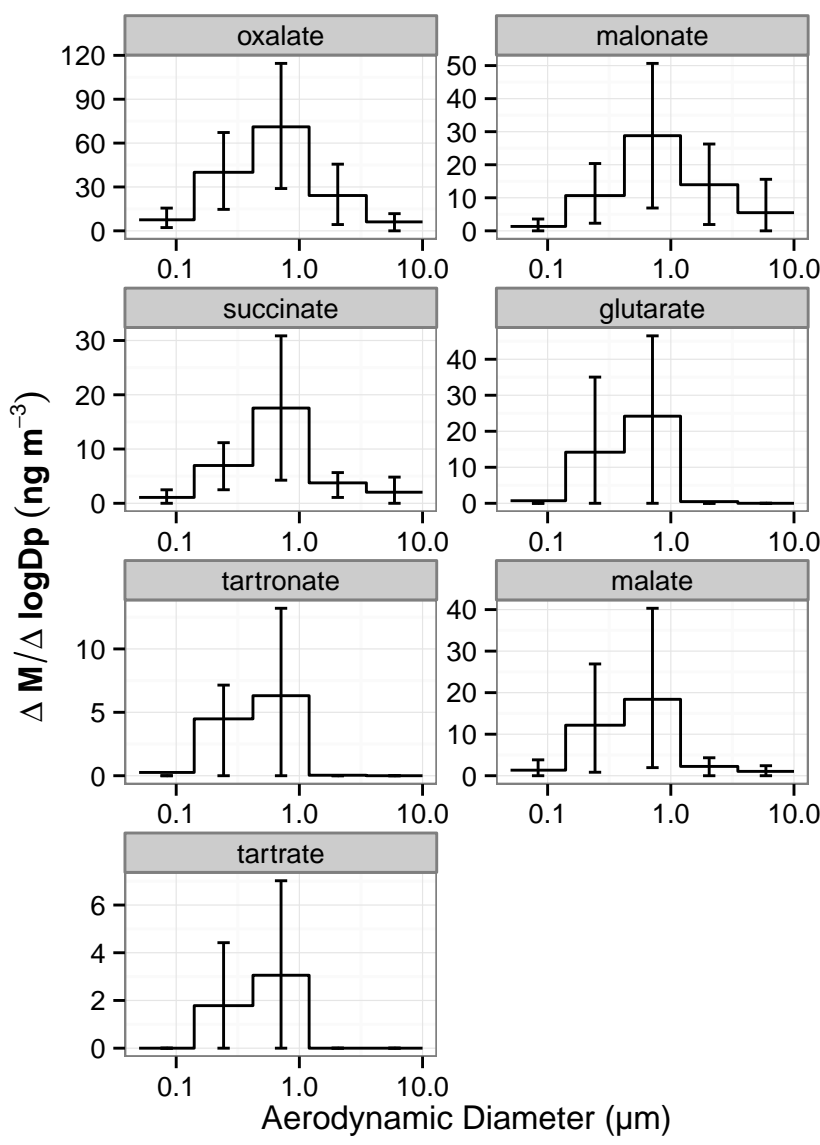

Fig. 1. Mean mass size distributions of DCAs at all sites. Error bars indicate the 15 th and 85 th percentiles as a measure of data variability.

components are shown, which basically describe the correlation of the variable with the component. Note that for better readability loadings with $|x|<0.2$ were considered insignificant and removed, while loadings with $|x| \geq 0.6$ were considered "high" and are printed bold.

\subsubsection{PC 1: anthropogenically influenced gasSOA}

The first rotated component (PC 1) explains the largest part of the total variance in the data set $(19 \%)$ and has significant loadings for all DCAs in basically all particle size ranges. Highest loadings are observed for DCAs in smallest $\left(D_{\mathrm{p}}=0.05-0.14 \mu \mathrm{m}\right)$ and largest $\left(D_{\mathrm{p}}=3.5-10 \mu \mathrm{m}\right)$ particles, while they tend to decrease towards accumulation mode particles $\left(D_{\mathrm{p}}=0.42-1.2 \mu \mathrm{m}\right)$ (even non-significant for succinic acid). The hydroxy-DCA malic acid shows a somewhat different behaviour with continuously decreasing loadings from smallest towards largest particle sizes. High loadings are also observed for the two solar flux variables and for $\mathrm{O}_{3}$. PC 1 likely represents photochemical formation of DCAs in the gas phase (gasSOA) during days with high intensity of solar radiation. The gas phase formation is inferred
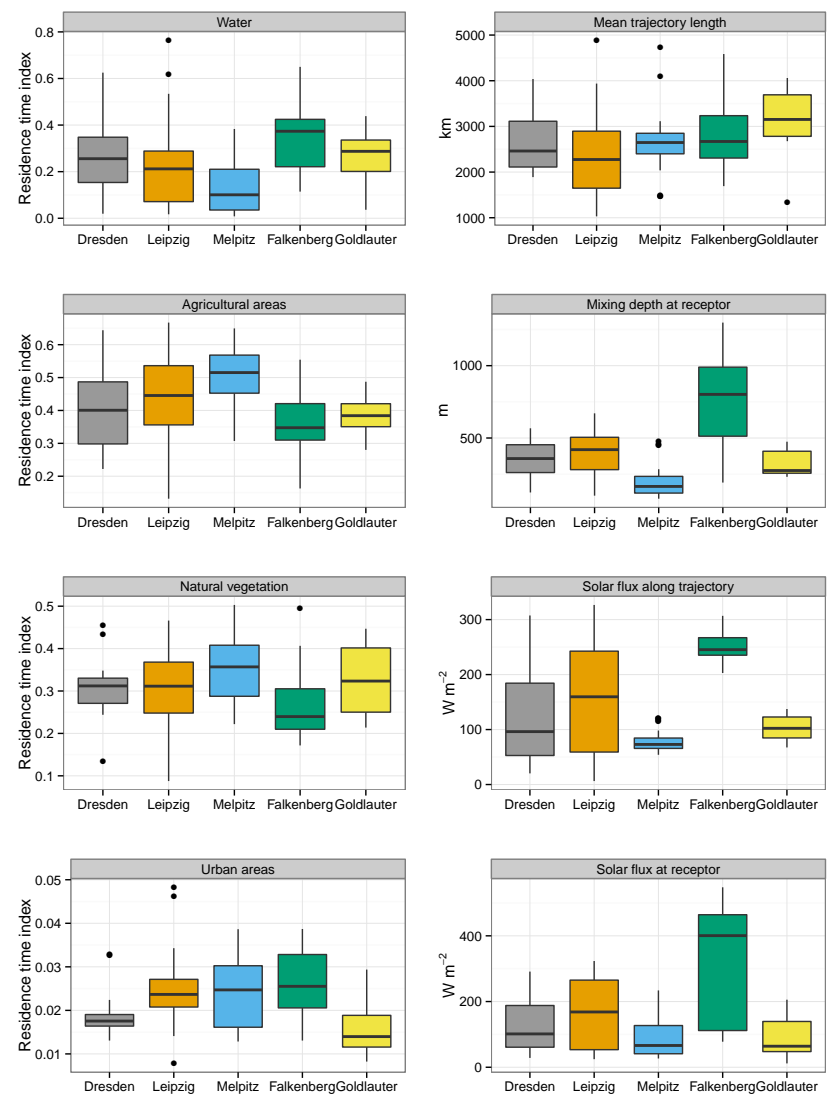

Fig. 2. Box plots of residence time indices and further parameters of back trajectory analysis at different sampling sites. Bold line represents median, boxes lower and upper quartiles, whiskers 1.5 times the interquartile range, and dots indicate values outside this range.

(i) from the typically low ambient relative humidity (RH) and cloud cover during such days, leading to low amounts of liquid water in the atmosphere and (ii) from the strongly increasing loadings towards smaller particle sizes, reflecting the higher surface area available for condensation. Regarding $\mathrm{RH}$, it has to be noted that it is strongly anti-correlated to the solar flux parameters in our data set and its inclusion to the PCA leads to strong negative loadings for both RH along the trajectory as well as $\mathrm{RH}$ at the receptor site (data not shown). Regarding particle sizes, the high loading of sulfate in very small particles is consistent with PC 1 representing a gas phase source, as gaseous formation and subsequent condensation of sulfuric acid is a well-known process under the influence of strong solar radiation (Hamed et al., 2010). The high loadings of DCAs in coarse particle size ranges might be explained by their repartitioning onto crustal material and/or mineral dust particles. Calcium - a typical crust component - has a quite high loading to PC 1 for the largest particle size range as well. Due to their less acidic character (Scheinhardt et al., 2013), the diacids might strongly condense to such particles despite the lower surface area they provide. Such a preferential partitioning of DCA has 
already been suggested previously (Kerminen et al., 2001). The different trend of malic acid loadings with respect to coarse particles is consistent with the lower vapour pressures of hydroxyl-DCAs and thus less favourable evaporation from smaller particles. Heterogeneous photochemical reactions on dust could be another plausible explanation for the observed coarse mode loadings. Regarding the timescale of the photochemical production of DCA in PC 1, the very similar magnitude of the two solar flux loadings indicate a rather local and thus quick formation. If major fractions of particulate DCAs would have been formed during previous days already and just been transported to the site, one could expect the solar flux along the back-trajectory loading to be higher than the local solar flux loading. Even though this might not be a very strong indication, it is consistent with a study on highly time-resolved oxalate concentrations, showing a strong diurnal profile during summer and thus a rather fast formation (Fisseha et al., 2006). Based on these indications, the timescale of gas phase DCA formation might be estimated to lie in the range of minutes to hours, depending on the photochemical conditions. A real quantitative discussion of formation kinetics is, however, not feasible from the data of the present study. Regarding the type of emissions, which might impact DCA formation in PC 1, the negative loading of mean trajectory length to PC 1 indicates comparatively short back-trajectories, thus rather high residence times above continental areas as compared to marine areas (where longer trajectories spend much of their travelling time for the given sampling sites of this study). It has to be noted, though, that all back trajectories of sampled air masses are well above $1000 \mathrm{~km}$ in mean trajectory length (Fig. 2). The negative loading of this parameter does therefore not indicate a local influence of emissions. In fact, local emissions cannot be resolved by the coarse resolution of trajectory calculation. Among the residence time indices, urban areas have the highest loading, followed by a minor loading of agricultural areas, and a non-significant loading of natural vegetation, indicating a significant influence of anthropogenic emissions to this factor. Overall, PC 1 likely represents secondary organic aerosol formed in the gas phase of polluted air masses (gasSOA) as an important source of DCAs.

\subsubsection{PC 2: anthropogenically influenced aqSOA}

The second rotated component (PC 2) explains another $15 \%$ of the total variance. Moderate to high loadings on PC 2 were found for all DCAs in the particle size range $D_{\mathrm{p}}=0.14$ $3.5 \mu \mathrm{m}$ (impactor stages 2 to 4 ) with maximum loadings in accumulation mode particles with $D_{\mathrm{p}}=0.42-1.2 \mu \mathrm{m}$. Similar loading patterns with highest values in medium-sized particles were observed for OC, EC, sulfate and potassium. Among the residence time indices, agricultural areas, urban areas and natural vegetation show high, moderate and small loadings, respectively. The mean trajectory length is anticorrelated to the component. PC 2 likely represents aged air

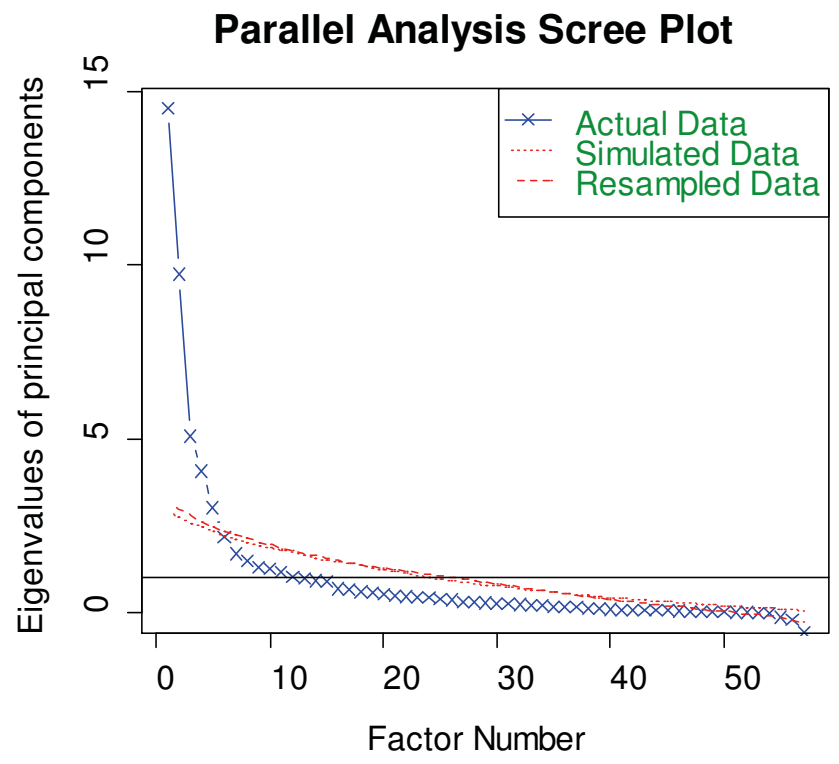

Fig. 3. Scree plot of PCA including results from parallel analysis.

masses with long residence times above continental areas and a strong input of anthropogenic emissions including biomass burning. The high loading of agricultural areas might reflect the impact of sources located outside urban areas, such as industrial facilities, roads and power plants. The moderate loading of $\mathrm{SO}_{2}$, whose main source in Europe is energy production (European Environment Agency, 2010), seems to support especially the latter suggestion. The solar flux parameters do not show significant loadings on PC 2, indicating that the formation of DCAs in this factor is not primarily driven by strong radiation. Together with the regional character of the source (highest loadings in accumulation mode particles), it can be assumed that DCA production takes place on a slower timescale (hours to days) as compared to PC 1. In principle, contributions from primary sources to $\mathrm{PC} 2$ cannot be excluded, as EC and - to a lesser extent - potassium correlate with the factor as well. However, the two primary sources which are most often discussed in the context of DCA emissions (traffic and biomass burning) are resolved by the model in PCs 3 and 4. PC 2 might thus represent the SOA from traffic and/or biomass burning, while PCs 3 and 4 represent their primary components. The similarity between sulfate and DCA loadings on PC 2 implies a high correlation of their concentrations in this source. Good correlation of sulfate with oxalate (and sometimes other DCAs) has often been reported from field studies (Yu et al., 2005; Sorooshian et al., 2006; Hsieh et al., 2007, 2008; Miyazaki et al., 2009) and can be taken as an indication of aqueous phase formation of DCAs (Yu et al., 2005; Sorooshian et al., 2006) due to aqueous $\mathrm{SO}_{2}$ oxidation being the dominant source of sulfate in the atmosphere (Yu et al., 2005). From size-resolved DCA measurements, a dominant "droplet mode" with $D_{\mathrm{p}}$ ca. 0.7$0.9 \mu \mathrm{m}$ as opposed to a less abundant "condensation mode" 
Table 2. Loadings of PCA after Varimax rotation. Loadings with $|x|<0.2$ are considered insignificant and removed, while loadings with $|x| \geq 0.6$ are considered as "high" and are printed bold.

\begin{tabular}{|c|c|c|c|c|c|c|}
\hline $\begin{array}{l}\text { Variable } \\
\text { Assigned source }\end{array}$ & $\begin{array}{r}\mathrm{PC} 1 \\
\text { gasSOA }\end{array}$ & $\begin{array}{r}\mathrm{PC} 2 \\
\text { aqSOA }\end{array}$ & $\begin{array}{r}\text { PC } 3 \\
\text { traffic }\end{array}$ & $\begin{array}{r}\mathrm{PC} 4 \\
\mathrm{BB}\end{array}$ & $\begin{array}{r}\text { PC } 5 \\
\text { sea salt }\end{array}$ & $\begin{array}{r}\text { PC } 6 \\
\text { soil }\end{array}$ \\
\hline Oxalate $0.05-0.14 \mu \mathrm{m}$ & 0.81 & & & & & \\
\hline Oxalate $0.14-0.42 \mu \mathrm{m}$ & 0.70 & 0.42 & -0.29 & & & \\
\hline Oxalate $0.42-1.2 \mu \mathrm{m}$ & 0.32 & 0.81 & & & & \\
\hline Oxalate $1.2-3.5 \mu \mathrm{m}$ & 0.53 & 0.29 & -0.42 & & 0.26 & 0.23 \\
\hline Oxalate $3.5-10 \mu \mathrm{m}$ & 0.69 & & & & 0.33 & 0.32 \\
\hline Malonate $0.05-0.14 \mu \mathrm{m}$ & 0.81 & & & & -0.22 & \\
\hline Malonate $0.14-0.42 \mu \mathrm{m}$ & 0.55 & 0.68 & -0.25 & & -0.29 & \\
\hline Malonate $0.42-1.2 \mu \mathrm{m}$ & 0.38 & 0.77 & & & & \\
\hline Malonate $1.2-3.5 \mu \mathrm{m}$ & 0.54 & 0.34 & -0.61 & & & 0.26 \\
\hline Malonate $3.5-10 \mu \mathrm{m}$ & 0.68 & & -0.58 & & & \\
\hline Succinate $0.05-0.14 \mu \mathrm{m}$ & 0.71 & & & & & \\
\hline Succinate $0.14-0.42 \mu \mathrm{m}$ & 0.35 & 0.80 & & & -0.34 & \\
\hline Succinate $0.42-1.2 \mu \mathrm{m}$ & & 0.88 & & & -0.23 & \\
\hline Succinate $1.2-3.5 \mu \mathrm{m}$ & 0.31 & 0.48 & -0.32 & & & 0.48 \\
\hline Succinate $3.5-10 \mu \mathrm{m}$ & 0.64 & & & -0.31 & & 0.42 \\
\hline Malate $0.05-0.14 \mu \mathrm{m}$ & 0.79 & & -0.20 & & -0.26 & -0.20 \\
\hline Malate $0.14-0.42 \mu \mathrm{m}$ & 0.70 & 0.40 & -0.47 & & & \\
\hline Malate $0.42-1.2 \mu \mathrm{m}$ & 0.43 & 0.72 & -0.44 & & & \\
\hline Malate $1.2-3.5 \mu \mathrm{m}$ & 0.32 & 0.28 & -0.70 & & & \\
\hline Malate $3.5-10 \mu \mathrm{m}$ & 0.23 & & -0.75 & & & \\
\hline OC $0.05-0.14 \mu \mathrm{m}$ & & & 0.33 & & -0.53 & 0.46 \\
\hline OC $0.14-0.42 \mu \mathrm{m}$ & & 0.25 & & & -0.38 & 0.43 \\
\hline OC $0.42-1.2 \mu \mathrm{m}$ & & 0.56 & & & -0.44 & 0.31 \\
\hline OC $1.2-3.5 \mu \mathrm{m}$ & & 0.28 & & & & 0.61 \\
\hline OC $3.5-10 \mu \mathrm{m}$ & 0.49 & & & & & 0.36 \\
\hline EC $0.05-0.14 \mu \mathrm{m}$ & 0.20 & & 0.59 & & & 0.40 \\
\hline EC $0.14-0.42 \mu \mathrm{m}$ & & 0.55 & 0.40 & & & 0.28 \\
\hline EC $0.42-1.2 \mu \mathrm{m}$ & & 0.61 & 0.36 & & & \\
\hline EC $1.2-3.5 \mu \mathrm{m}$ & & 0.39 & 0.31 & & & 0.51 \\
\hline EC $3.5-10 \mu \mathrm{m}$ & 0.53 & & & & & 0.45 \\
\hline Sulfate $0.05-0.14 \mu \mathrm{m}$ & 0.62 & 0.21 & & 0.40 & & \\
\hline Sulfate $0.14-0.42 \mu \mathrm{m}$ & 0.20 & 0.63 & & 0.49 & & \\
\hline Sulfate $0.42-1.2 \mu \mathrm{m}$ & & 0.90 & & 0.22 & & \\
\hline Sulfate $1.2-3.5 \mu \mathrm{m}$ & & 0.50 & & & 0.23 & 0.40 \\
\hline Sulfate $3.5-10 \mu \mathrm{m}$ & & & & 0.41 & 0.56 & 0.33 \\
\hline Potassium $0.05-0.14 \mu \mathrm{m}$ & & & & 0.69 & & \\
\hline Potassium $0.14-0.42 \mu \mathrm{m}$ & & 0.32 & 0.29 & 0.71 & & \\
\hline Potassium $0.42-1.2 \mu \mathrm{m}$ & -0.24 & 0.37 & 0.40 & 0.62 & & \\
\hline Potassium $1.2-3.5 \mu \mathrm{m}$ & & & & 0.81 & & \\
\hline Potassium $3.5-10 \mu \mathrm{m}$ & 0.20 & & & 0.65 & 0.38 & -0.22 \\
\hline Sodium $0.42-1.2 \mu \mathrm{m}$ & & & & 0.62 & 0.29 & \\
\hline Sodium $1.2-3.5 \mu \mathrm{m}$ & & -0.20 & & & 0.79 & \\
\hline Sodium $3.5-10 \mu \mathrm{m}$ & & -0.26 & & & 0.83 & \\
\hline Calcium $0.42-1.2 \mu \mathrm{m}$ & & & & 0.72 & -0.20 & \\
\hline Calcium $1.2-3.5 \mu \mathrm{m}$ & 0.33 & & & 0.33 & & 0.54 \\
\hline Calcium $3.5-10 \mu \mathrm{m}$ & 0.58 & & & 0.28 & & 0.35 \\
\hline $\mathrm{O}_{3}$ & 0.46 & & & -0.54 & & -0.48 \\
\hline $\mathrm{NO}_{\mathrm{x}}$ & 0.26 & & 0.82 & & & 0.29 \\
\hline $\mathrm{CO}$ & & & 0.58 & & & \\
\hline $\mathrm{SO}_{2}$ & -0.21 & 0.34 & 0.37 & 0.57 & & 0.22 \\
\hline RTI $_{\text {Natural Vegetation }}$ & & 0.29 & & & -0.71 & \\
\hline $\mathrm{RTI}_{\text {Agriculture }}$ & 0.25 & 0.68 & & & -0.40 & \\
\hline $\mathrm{RTI}_{\text {Urban Areas }}$ & 0.44 & 0.37 & & & & \\
\hline Mean trajectory length & -0.46 & -0.41 & & & 0.39 & \\
\hline Solar flux along trajectory & 0.79 & & -0.42 & & & \\
\hline Solar flux at receptor & 0.78 & & -0.26 & & & -0.27 \\
\hline Mixing depth at receptor & 0.52 & & -0.30 & & 0.39 & -0.44 \\
\hline Explained variance $(\%)$ & 18 & 15 & 10 & 9 & 8 & 7 \\
\hline Cumulative variance (\%) & 18 & 34 & 44 & 53 & 61 & 68 \\
\hline
\end{tabular}


with $D_{\mathrm{p}}$ ca. $0.2-0.4 \mu \mathrm{m}$ can be taken as evidence for aqueous phase formation as well (Yao et al., 2003; Hsieh et al., 2009; Lan et al., 2011), in analogy to earlier discussions on the abundance of sulfate in these two particle modes (Hering and Friedlander, 1982; John et al., 1990; Meng and Seinfeld, 1994). Both lines of thought (correlation with aqueous phase formed sulfate and aqueous phase production leading to a "droplet mode") are supported to some extent by PC 2 as well (high loadings of DCAs and sulfate as well as highest loadings in "droplet mode" size range). RH during sampling did not help to further elucidate the role of aqueous chemistry in our data set, as PCA runs with RH included resulted in insignificant loadings to PC 2. Even though more direct evidence of aqueous phase formation would be desirable (e.g. the concentrations of aqueous phase oxidants or the amount of available particle and/or cloud water), it can be concluded that aqueous phase formation of DCAs likely plays an important role in the source resolved by PC 2 and it can thus be attributed to aqueous phase SOA (aqASOA) with a significant anthropogenic influence on either the precursors and/or the oxidant chemistry.

\subsubsection{PC 3: traffic}

The third rotated component (PC 3) explains $10 \%$ of the variance and has high positive loadings for $\mathrm{NO}_{\mathrm{x}}$ and $\mathrm{CO}$. EC shows a high loading in ultrafine particles $\left(D_{\mathrm{p}}=0.05-\right.$ 0.14 ) and moderate and continuously decreasing loadings in larger particle size fractions, while the solar flux parameters and the mixing depth at the receptor site have negative loadings. PC 3 can clearly be attributed to a traffic source, presumably in wintertime conditions, where pollution can build up quickly due to less efficient boundary layer mixing processes. All significant DCA loadings on PC 3 are negative, thus strongly implying that primary traffic emissions are not a significant source of DCAs in this data set.

\subsubsection{PC 4: biomass burning}

The fourth rotated component (PC 4) explains another 9\% of the total data variance and contains mainly potassium with high loadings in all particle size ranges. In addition, sulfate, sodium and calcium show significant loadings within some size ranges and $\mathrm{SO}_{2}$ has a rather strong loading as well. As fine-particle potassium is a classical tracer of biomass burning (Khalil and Rasmussen, 2003), PC 4 is assumed to represent a primary biomass burning source. No DCA variable loads significantly on this factor, which is why biomass burning is unlikely to be a primary source of DCAs in the present study.

\subsubsection{PC 5: sea salt}

The fifth rotated component (PC 5) explains $8 \%$ of the total variance. High loadings of coarse mode sodium together with moderate loadings of coarse mode sulfate are observed. The mean trajectory length shows a moderate positive loading, while the residence time indices for natural vegetation and agriculture are anticorrelated to the factor. PC 5 can be attributed to (processed) sea salt. Among the DCAs, only oxalate in coarse mode particles shows small loadings, while other DCAs have either insignificant or negative loadings. Sea salt might thus contribute to some small extent to coarse mode oxalate concentrations at continental sites in Germany. A sea salt mode of DCA is usually observed in marine regions (Kerminen et al., 1999, 2000; Neusüß et al., 2000; Mochida et al., 2003b). Whether the oxalate measured at the inland sites of this study indeed originates from sea salt or from the processing of these particles on their way to the receptor sites (e.g. by condensation to less acidic sea salt particles) cannot be concluded from the data, though.

\subsubsection{PC 6: soil}

The sixth rotated component (PC 6) explains $7 \%$ of the data variance and contains moderate to high loadings of $\mathrm{OC}$ in all particle size ranges and of sulfate and calcium in coarse mode particles. EC shows significant loadings in small and large particles, while minor loadings are observed for a few other variables. Based on this loadings pattern the attribution of a source to this factor is less evident than for the previous components. Mainly due to the loadings of calcium, sulfate and OC, PC 6 is tentatively interpreted as a primary soil source. The EC loadings might then result from complex high-molecular-weight soil organic matter (humic substances), which does not likely fully evaporate at $650^{\circ} \mathrm{C}$ and is thus incorrectly attributed to the $\mathrm{EC}$ fraction of total particulate carbon in our method of OC/EC determination. Among the DCAs, minor loadings of coarse mode oxalate and malonate are observed, while coarse mode succinic acid shows moderate loadings to this factor. Organic acids, including the DCAs of this study, are known to be important constituents of soil organic matter (Jones, 1998), thus resuspended soil in coarse mode particles can be assumed to contribute to coarse mode DCA concentrations.

As discussed above, a seven-factor solution for the PCA could in principle be justified from the scree plot as well. The main difference to the six-factor solution is that the loadings of the original PC 6 are then distributed between the new PC 6 and PC 7, i.e. PC 6 seems to be split into two factors. One factor tends to hold the loadings on impactor stage $4\left(D_{\mathrm{p}}=1.2-3.5 \mu \mathrm{m}\right)$, while the other tends to take over the stage-5 $\left(D_{\mathrm{p}}=3.5-10 \mu \mathrm{m}\right)$ loadings to some extent. The variables for which significant loadings are observed for the new PC 6 and PC 7 are the same as for the original PC 6 discussed here. The interpretability of the new PC 6 and PC 7 is even 
more ambiguous than for the original PC 6 . This is why the seven-factor solution has been considered to resolve two artificial sources instead of one real one and has been discarded.

\subsection{Discussion of main DCA sources}

The results of the PCA show that the major part of the variance of DCAs in different particle size ranges can be attributed to two main sources: (1) fast photochemical formation during intense radiation days, likely due to gas phase oxidation of precursors in anthropogenically influenced air masses (gasSOA), and (2) slower, but presumably more continuous, secondary formation in anthropogenically polluted air masses, possibly with an important contribution of aqueous phase oxidation processes (aqSOA). Much smaller contributions to the abundance of LMW-DCAs can be expected from primary biomass burning emissions, (processed) sea salt and primary soil emissions.

While the importance of secondary processes in the formation of LMW-DCAs is well established, they are typically assumed to be products of aqueous phase reactions (Kanakidou et al., 2005; Ervens et al., 2011). From the results of this study, however, a significant contribution from gas phase reactions seems possible (PC 1) under certain conditions. For the $10 \%$ of samples which have the highest scores on PC 1 (i.e. the days with presumably the highest impact of gasSOA) the sum of impactor stage 1 and 2 $\left(D_{\mathrm{p}}=0.05-0.42 \mu \mathrm{m}\right)$ concentrations for a given DCA typically makes up $45-55 \%$ of its total $\mathrm{PM}_{1}$ and $30-55 \%$ of its total $\mathrm{PM}_{10}$ concentration. Making the (very crude) assumption that stage 1 and stage 2 concentrations represent DCAs formed solely from gas phase oxidation processes, these results would indicate that roughly up to one third to one half of total DCA concentrations can be attributed to gas phase sources under appropriate conditions. Given, however, that condensed phase reactions likely contribute to DCA concentrations in these particle sizes (impactor stages 1 and 2) as well, the contribution of gas phase sources to total DCA concentrations will likely be lower. To the best of the authors' knowledge, the formation of LMW-DCAs is at present not included in comprehensive atmospheric gas phase chemistry models. For example, none of the DCAs determined in this study are incorporated in the Master Chemical Mechanism v3.2 (http://mcm.leeds.ac.uk/MCM). Two possibilities of gas phase formation of organic acids are well known, though: (i) ozonolysis of unsaturated compounds (see Orzechowska and Paulson (2005) and references therein) and (ii) the reactions of acylperoxy radicals with hydroperoxyl $\left(\mathrm{HO}_{2}\right)$ radicals (see Calvert et al., 2011 and references therein). Ozonolysis of semi-volatile unsaturated fatty acids has since long been suggested as a possible source of LMW-DCAs in the atmosphere (Kawamura et al., 1996a) and DCAs have frequently been observed in the aerosol phase in chamber studies of unsaturated hydrocarbons (Hatakeyama et al., 1985, 1987; Kalberer et al., 2000; Fisseha et al., 2004; Gao et al., 2004; Hamilton et al., 2006; Sato et al., 2007; Sorooshian et al., 2007; Borras and Tortajada-Genaro, 2012). Depending on the position of the $\mathrm{C}-\mathrm{C}$ double bond in the monocarboxylic acid precursor, the $\mathrm{C} 2$ to C5 DCAs observed in this study could easily result from such reactions. Ozone has recently been suggested to be an important driver in the formation of carboxylic acid containing SOA (Liu et al., 2011) and it is correlated with PC 1 in our study as well. The oxidation of $\omega$-oxo-monocarboxylic acids to DCAs has also been proposed in the past (Kawamura et al., 1996a). This reaction would proceed via abstraction of the aldehydic $\mathrm{H}$ atom (e.g. by hydroxyl radicals $(\mathrm{OH})$ ), addition of molecular oxygen and reaction of the formed acylperoxy radical with $\mathrm{HO}_{2}$ to result in the corresponding DCA. The relevance of these qualitatively feasible formation pathways, however, depends on their competition with the manifold of other reaction channels in the case of ozonolysis (Orzechowska and Paulson, 2005) and - for continental conditions - mainly with the reaction of acylperoxy radicals with NO, leading to chain-shortened aldehydes (Calvert et al., 2011). In general, these pathways can be expected to be of minor importance only, although kinetic data and product studies of relevant precursors (unsaturated or oxygenated acids) are very limited (Calvert et al., 2011). If the concentrations of precursors (and oxidants) are high enough, however, they might significantly contribute to the observed LMWDCA concentrations even in low yields.

Another possible gas phase formation pathway of carboxylic acids could be the reaction of enols with $\mathrm{OH}$. Recently, the common assumption of keto-enol tautomerization of gas phase aldehydes and ketones being negligible in the atmosphere has been challenged by both theoretical and experimental studies (da Silva, 2010; Andrews et al., 2012; Clubb et al., 2012). It was suggested that a significant proportion of carbonyl compounds might exist in their (highly reactive) enol form. Addition of $\mathrm{OH}$ to the $\mathrm{C}-\mathrm{C}$ double bond then results in a carboxylic acid to be formed, which could account for the discrepancies between typical modelled versus measured budgets of organic acids in the atmosphere (Archibald et al., 2007). This could hypothetically be another pathway for the gas phase oxidation of keto-acids to LMW-DCAs. Naturally, much more thermodynamic and kinetic data and implementation into models is needed to assess the relevance of such a formation pathway.

Despite a potential relevance of gas phase processes (PC 1), in terms of total DCA concentrations, PC 2 likely represents the most important source, as highest concentrations of DCAs are typically observed on impactor stages 2 and $3\left(D_{\mathrm{p}}=0.14-1.2 \mu \mathrm{m}\right.$, see Fig. 1$)$. This is in line with the acknowledged importance of aqueous phase oxidation processes on the formation of LMW-DCAs in the atmosphere (Tilgner and Herrmann, 2010; Ervens et al., 2011). Water-soluble products of volatile organic compound (VOC) oxidation can readily be taken up by deliquesced particles and cloud droplets. Especially by the hydration of aldehyde groups to gem-diols, this uptake opens a reaction channel 
towards carboxylic acids which is not available in the gas phase.

As outlined above (Introduction), the precursors of DCAs are numerous and can originate from both continental and marine as well as from anthropogenic and biogenic sources. For the sampling sites of the present study, the results of back-trajectory analysis suggest that continental sources dominate (negative correlation with trajectory length) and indicate an influence of anthropogenic activities on the DCA concentrations for both PC 1 (correlation with urban areas RTI) and PC 2 (correlation with agriculture and urban areas RTI). It has to be noted that correlations with primary anthropogenic trace gases are weak or even absent in accordance with the secondary nature of the two main sources, which implies highest concentrations away from direct sources (dispersion/dilution of trace gases). These results might indicate the importance of anthropogenic precursors on DCA concentrations. There is, however, evidence from several field studies on SOA formation that despite a strong anthropogenic influence to the studied air masses (typically deduced from correlations with anthropogenic tracers), a dominant fraction of carbonaceous material is composed of modern carbon (in contrast to fossil carbon) and thus originates from biogenic sources (Weber et al., 2007; Worton et al., 2011; El Haddad et al., 2013). The coupling of an anthropogenic and biogenic component in sampled air masses has been suggested to potentially enhance biogenic SOA formation, e.g. through higher oxidant concentrations due to higher $\mathrm{NO}_{\mathrm{x}}$ and/or higher partitioning of biogenic SOA due to higher concentrations of (primary or secondary) anthropogenic organic aerosol (Carlton et al., 2010). Thus, in the absence of additional data, firm conclusions on the nature of DCA precursor VOCs cannot easily be drawn.

\section{Conclusions}

A relatively large set of size-resolved samples of aerosol particles has been used to study the abundance of LMW-DCA in different particle size ranges at several continental sites in Germany. PCA was used to qualitatively distinguish between different sources and formation pathways. Together with additional data from back-trajectory analysis and trace gas measurements, two main sources of DCA could be identified: photochemical formation in the gas phase, strongly affecting concentrations of small and large particles, and secondary formation via aqueous phase processes, leading to increased concentrations in accumulation mode particles mainly. For both sources, an anthropogenic influence is apparent from the back-trajectory analysis, either by providing the precursors for DCA formation, or by triggering enhanced biogenic SOA formation, e.g. through increased oxidant levels. The relative importance of these sources will be different in different seasons with photochemical gas phase formation being most important in summer. How it differs between different sites likely depends on the nature of precursors and their possibly complex interactions and will need to be addressed in future studies. Compared to the secondary sources, primary emissions of DCAs from traffic, biomass burning, sea salt and soil are considered to contribute much less or even nothing at all to the concentrations of DCAs at the sites studied. The results of this study suggest that beyond the well-known importance of aqueous phase formation, gas phase formation of LMW-DCAs can be important under conditions of high photochemistry in anthropogenically influenced air masses as well.

\section{Supplementary material related to this article is available online at http://www.atmos-chem-phys.net/14/ 3913/2014/acp-14-3913-2014-supplement.pdf.}

Acknowledgements. Financial support for the campaigns was granted by the German Federal Ministry of Education and Research (BMBF) as part of the projects 07AF102A/1 (MINT, Melpitz) and 07AF302/6 (LACE, Falkenberg) within the German AFS framework and as part of the project 07ATF01 (FEBUKO, Goldlauter) within the AFO2000 framework. Financial support for the measurements in Dresden and Leipzig was received from the Saxon State Ministry of the Environment and Agriculture and the Forschungsvereinigung Automobiltechnik e.V., respectively.

Edited by: V.-M. Kerminen

\section{References}

Agarwal, S., Aggarwal, S. G., Okuzawa, K., and Kawamura, K.: Size distributions of dicarboxylic acids, ketoacids, $\alpha$ dicarbonyls, sugars, WSOC, OC, EC and inorganic ions in atmospheric particles over Northern Japan: implication for long-range transport of Siberian biomass burning and East Asian polluted aerosols, Atmos. Chem. Phys., 10, 5839-5858, doi:10.5194/acp10-5839-2010, 2010.

Allen, A. G., Cardoso, A. A., and da Rocha, G. O.: Influence of sugar cane burning on aerosol soluble ion composition in Southeastern Brazil, Atmos. Environ., 38, 5025-5038, 2004.

Andrews, D. U., Heazlewood, B. R., Maccarone, A. T., Conroy, T., Payne, R. J., Jordan, M. J. T., and Kable, S. H.: PhotoTautomerization of Acetaldehyde to Vinyl Alcohol: A Potential Route to Tropospheric Acids, Science, 337, 1203-1206, doi:10.1126/science.1220712, 2012.

Archibald, A. T., McGillen, M. R., Taatjes, C. A., Percival, C. J., and Shallcross, D. E.: Atmospheric transformation of enols: A potential secondary source of carboxylic acids in the urban troposphere, Geophys. Res. Lett., 34, L21801, doi:10.1029/2007g1031032, 2007.

Bardouki, H., Liakakou, H., Economou, C., Sciare, J., Smolík, J., Zdímal, V., Eleftheriadis, K., Lazaridis, M., Dye, C., and Mihalopoulos, N.: Chemical composition of size-resolved atmospheric aerosols in the eastern Mediterranean during summer and winter, Atmos. Environ., 37, 195-208, 2003. 
Booth, A. M., Topping, D. O., McFiggans, G., and Percival, C. J.: Surface tension of mixed inorganic and dicarboxylic acid aqueous solutions at $298.15 \mathrm{~K}$ and their importance for cloud activation predictions, Phys. Chem. Chem. Phys., 11, 8021-8028, doi:10.1039/B906849j, 2009.

Borras, E. and Tortajada-Genaro, L. A.: Secondary organic aerosol formation from the photo-oxidation of benzene, Atmos. Environ., 47, 154-163, doi:10.1016/j.atmosenv.2011.11.020, 2012.

Brüggemann, E. and Rolle, W.: Changes of some components of precipitation in East Germany after the unification, Water Air Soil Poll., 107, 1-23, 1998.

Brüggemann, E., Gerwig, H., Gnauk, T., Müller, K., and Herrmann, H.: Influence of seasons, air mass origin and day of the week on size-segregated chemical composition of aerosol particles at a kerbside, Atmos. Environ., 43, 2456-2463, doi:10.1016/j.atmosenv.2009.01.054, 2009.

Calvert, J. G., Mellouki, A., Orlando, J. J., Pilling, M. J., and Wallington, T. J.: The mechanisms of atmospheric oxidation of the oxygenates, Oxford University Press, New York, 2011.

Carlton, A. G., Turpin, B. J., Lim, H. J., Altieri, K. E., and Seitzinger, S.: Link between isoprene and secondary organic aerosol (SOA): Pyruvic acid oxidation yields low volatility organic acids in clouds, Geophys. Res. Lett., 33, L06822, doi:10.1029/2005g1025374, 2006.

Carlton, A. G., Pinder, R. W., Bhave, P. V., and Pouliot, G. A.: To What Extent Can Biogenic SOA be Controlled?, Environ. Sci. Technol., 44, 3376-3380, doi:10.1021/Es903506b, 2010.

Cattell, R. B.: The scree test for the number of factors, Multivar. Behav. Res., 1, 245-276, 1966.

Choi, M. Y. and Chan, C. K.: The effects of organic species on the hygroscopic behaviors of inorganic aerosols, Environ. Sci. Technol., 36, 2422-2428, 2002.

Clubb, A. E., Jordan, M. J. T., Kable, S. H., and Osborn, D. L.: Phototautomerization of Acetaldehyde to Vinyl Alcohol: A Primary Process in UV-Irradiated Acetaldehyde from 295 to $335 \mathrm{~nm}$, J. Phys. Chem. Lett., 3, 3522-3526, doi:10.1021/jz301701x, 2012.

da Silva, G.: Carboxylic Acid Catalyzed Keto-Enol Tautomerizations in the Gas Phase, Angew. Chem. Int. Edit., 49, 7523-7525, doi:10.1002/anie.201003530, 2010.

Draxler, R. R. and Hess, G. D.: An overview of the HYSPLIT_4 modeling system of trajectories, dispersion, and deposition, Aust. Meteorol. Mag., 47, 295-308, 1998.

El Haddad, I., D’Anna, B., Temime-Roussel, B., Nicolas, M., Boreave, A., Favez, O., Voisin, D., Sciare, J., George, C., Jaffrezo, J.-L., Wortham, H., and Marchand, N.: Towards a better understanding of the origins, chemical composition and aging of oxygenated organic aerosols: case study of a Mediterranean industrialized environment, Marseille, Atmos. Chem. Phys., 13, 78757894, doi:10.5194/acp-13-7875-2013, 2013.

Ervens, B., Carlton, A. G., Turpin, B. J., Altieri, K. E., Kreidenweis, S. M., and Feingold, G.: Secondary organic aerosol yields from cloud-processing of isoprene oxidation products, Geophys. Res. Lett., 35, L02816, doi:10.1029/2007g1031828, 2008.

Ervens, B., Turpin, B. J., and Weber, R. J.: Secondary organic aerosol formation in cloud droplets and aqueous particles (aqSOA): a review of laboratory, field and model studies, Atmos. Chem. Phys., 11, 11069-11102, doi:10.5194/acp-1111069-2011, 2011.
European Environment Agency: Sector share of sulphur oxides emissions - 2010, http://www.eea.europa.eu/data-and-maps/ figures/ds_resolveuid/4b414b0cfe27461b8ab75b8a455c1e8e (last access: 10 October 2013), 2010.

Falkovich, A. H., Graber, E. R., Schkolnik, G., Rudich, Y., Maenhaut, W., and Artaxo, P.: Low molecular weight organic acids in aerosol particles from Rondônia, Brazil, during the biomassburning, transition and wet periods, Atmos. Chem. Phys., 5, 781797, doi:10.5194/acp-5-781-2005, 2005.

Fisseha, R., Dommen, J., Sax, M., Paulsen, D., Kalberer, M., Maurer, R., Hofler, F., Weingartner, E., and Baltensperger, U.: Identification of organic organic aerosol and the acids in secondary corresponding gas phase from chamber experiments, Anal. Chem., 76, 6535-6540, 2004.

Fisseha, R., Dommen, J., Gaeggeler, K., Weingartner, E., Samburova, V., Kalberer, M., and Baltensperger, U.: Online gas and aerosol measurement of water soluble carboxylic acids in Zurich, J. Geophys. Res.-Atmos., 111, D12316, doi:10.1029/2005jd006782, 2006.

Fraser, M. P., Cass, G. R., and Simoneit, B. R. T.: Gas-phase and particle-phase organic compounds emitted from motor vehicle traffic in a Los Angeles roadway tunnel, Environ. Sci. Technol., 32, 2051-2060, 1998.

Gao, S., Hegg, D. A., Hobbs, P. V., Kirchstetter, T. W., Magi, B. I., and Sadilek, M.: Water-soluble organic components in aerosols associated with savanna fires in southern Africa: Identification, evolution, and distribution, J. Geophys. Res.-Atmos., 108, 8491, doi:10.1029/2002jd002324, 2003.

Gao, S., Keywood, M., Ng, N. L., Surratt, J., Varutbangkul, V., Bahreini, R., Flagan, R. C., and Seinfeld, J. H.: Low-molecularweight and oligomeric components in secondary organic aerosol from the ozonolysis of cycloalkenes and alpha-pinene, J. Phys. Chem. A, 108, 10147-10164, 2004.

Gnauk, T., Brüggemann, E., Müller, K., Chemnitzer, R., Rüd, C., Galgon, D., Wiedensohler, A., Acker, K., Auel, R., Wieprecht, W., Möller, D., Jaeschke, W., and Herrmann, H.: Aerosol characterisation at the FEBUKO upwind station Goldlauter (I): Particle mass, main ionic components, OCEC, and mass closure, Atmos. Environ., 39, 4209-4218, 2005.

Gnauk, T., Müller, K., van Pinxteren, D., He, L. Y., Niu, Y. W., Hu, M., and Herrmann, H.: Size-segregated particulate chemical composition in Xinken, Pearl River Delta, China: OC/EC and organic compounds, Atmos. Environ., 42, 62966309, doi:10.1016/j.atmosenv.2008.05.001, 2008.

Gómez-González, Y., Wang, W., Vermeylen, R., Chi, X., Neirynck, J., Janssens, I. A., Maenhaut, W., and Claeys, M.: Chemical characterisation of atmospheric aerosols during a 2007 summer field campaign at Brasschaat, Belgium: sources and source processes of biogenic secondary organic aerosol, Atmos. Chem. Phys., 12, 125-138, doi:10.5194/acp-12-125-2012, 2012.

Graham, B., Mayol-Bracero, O. L., Guyon, P., Roberts, G. C., Decesari, S., Facchini, M. C., Artaxo, P., Maenhaut, W., Koll, P., and Andreae, M. O.: Water-soluble organic compounds in biomass burning aerosols over Amazonia - 1. Characterization by NMR and GC-MS, J. Geophys. Res.-Atmos., 107, 8047, doi:10.1029/2001jd000336, 2002.

Hamed, A., Birmili, W., Joutsensaari, J., Mikkonen, S., Asmi, A., Wehner, B., Spindler, G., Jaatinen, A., Wiedensohler, A., Korhonen, H., Lehtinen, K. E. J., and Laaksonen, A.: Changes in the 
production rate of secondary aerosol particles in Central Europe in view of decreasing $\mathrm{SO}_{2}$ emissions between 1996 and 2006, Atmos. Chem. Phys., 10, 1071-1091, doi:10.5194/acp-10-10712010, 2010.

Hamilton, J. F., Lewis, A. C., Reynolds, J. C., Carpenter, L. J., and Lubben, A.: Investigating the composition of organic aerosol resulting from cyclohexene ozonolysis: low molecular weight and heterogeneous reaction products, Atmos. Chem. Phys., 6, 49734984, doi:10.5194/acp-6-4973-2006, 2006.

Hatakeyama, S., Tanonaka, T., Weng, J. H., Bandow, H., Takagi, H., and Akimoto, H.: Ozone cyclohexene reaction in air: Quantitative analysis of particulate products and the reaction mechanism, Environ. Sci. Technol., 19, 935-942, 1985.

Hatakeyama, S., Ohno, M., Weng, J. H., Takagi, H., and Akimoto, H.: Mechanism for the formation of gaseous and particulate products from ozone-cycloalkene reactions in air, Environ. Sci. Technol., 21, 52-57, 1987.

Hering, S. V. and Friedlander, S. K.: Origins of Aerosol Sulfur Size Distributions in the Los-Angeles Basin, Atmos. Environ., 16, 2647-2656, 1982.

Horn, J.: A rationale and test for the number of factors in factor analysis, Psychometrika, 30, 179-185, 1965.

Hsieh, L. Y., Kuo, S. C., Chen, C. L., and Tsai, Y. I.: Origin of lowmolecular-weight dicarboxylic acids and their concentration and size distribution variation in suburban aerosol, Atmos. Environ., 41, 6648-6661, doi:10.1016/j.atmosenv.2007.04.014, 2007.

Hsieh, L. Y., Chen, C. L., Wan, M. W., Tsai, C. H., and Tsai, Y. I.: Speciation and temporal characterization of dicarboxylic acids in $\mathrm{PM}_{2.5}$ during a $\mathrm{PM}$ episode and a period of non-episodic pollution, Atmos. Environ., 42, 6836-6850, doi:10.1016/j.atmosenv.2008.05.021, 2008.

Hsieh, L. Y., Kuo, S. C., Chen, C. L., and Tsai, Y. I.: Size distributions of nano/micron dicarboxylic acids and inorganic ions in suburban PM episode and non-episodic aerosol, Atmos. Environ., 43, 4396-4406, doi:10.1016/j.atmosenv.2009.04.034, 2009.

Huang, X. F. and Yu, J. Z.: Is vehicle exhaust a significant primary source of oxalic acid in ambient aerosols?, Geophys. Res. Lett., 34, L02808, doi:10.1029/2006g1028457, 2007.

Huang, X. F., Hu, M., He, L. Y., and Tang, X. Y.: Chemical characterization of water-soluble organic acids in $\mathrm{PM}_{2.5}$ in Beijing, China, Atmos. Environ., 39, 2819-2827, 2005.

Hyder, M., Genberg, J., Sandahl, M., Swietlicki, E., and Jonsson, J. A.: Yearly trend of dicarboxylic acids in organic aerosols from south of Sweden and source attribution, Atmos. Environ., 57, 197-204, doi:10.1016/j.atmosenv.2012.04.027, 2012.

Ion, A. C., Vermeylen, R., Kourtchev, I., Cafmeyer, J., Chi, X., Gelencsér, A., Maenhaut, W., and Claeys, M.: Polar organic compounds in rural $\mathrm{PM}_{2.5}$ aerosols from K-puszta, Hungary, during a 2003 summer field campaign: Sources and diel variations, Atmos. Chem. Phys., 5, 1805-1814, doi:10.5194/acp-5-1805-2005, 2005.

Jaffrezo, J. L., Davidson, C. I., Kuhns, H. D., Bergin, M. H., Hillamo, R., Maenhaut, W., Kahl, J. W., and Harris, J. M.: Biomass burning signatures in the atmosphere of central Greenland, J. Geophys. Res.-Atmos., 103, 31067-31078, 1998.

John, W., Wall, S. M., Ondo, J. L., and Winklmayr, W.: Modes in the Size Distributions of Atmospheric Inorganic Aerosol, Atmos. Environ. A-Gen., 24, 2349-2359, 1990.
Jolliffe, I. T.: Principal Component Analysis, 2nd Edn., Springer Series in Statistics, Springer, New York, 2002.

Jones, D. L.: Organic acids in the rhizosphere - a critical review, Plant Soil, 205, 25-44, 1998.

Kalberer, M., Yu, J., Cocker, D. R., Flagan, R. C., and Seinfeld, J. H.: Aerosol Formation in the Cyclohexene-Ozone System, Environ. Sci. Technol., 34, 4894-4901, doi:10.1021/es001180f, 2000.

Kanakidou, M., Seinfeld, J. H., Pandis, S. N., Barnes, I., Dentener, F. J., Facchini, M. C., Van Dingenen, R., Ervens, B., Nenes, A., Nielsen, C. J., Swietlicki, E., Putaud, J. P., Balkanski, Y., Fuzzi, S., Horth, J., Moortgat, G. K., Winterhalter, R., Myhre, C. E. L., Tsigaridis, K., Vignati, E., Stephanou, E. G., and Wilson, J.: Organic aerosol and global climate modelling: a review, Atmos. Chem. Phys., 5, 1053-1123, doi:10.5194/acp-5-1053-2005, 2005.

Kawamura, K. and Kaplan, I. R.: Motor exhaust emissions as a primary source for dicarboxylic acids in Los Angeles ambient air, Environ. Sci. Technol., 21, 105-110, 1987.

Kawamura, K. and Usukura, K.: Distributions of Low Molecular Weight Dicarboxylic Acids in the North Pacific Aerosol Samples, J. Oceanogr., 49, 271-283, 1993.

Kawamura, K., Kasukabe, H., and Barrie, L. A.: Source and reaction pathways of dicarboxylic acids, ketoacids and dicarbonyls in arctic aerosols: One year of observations, Atmos. Environ., 30, 1709-1722, 1996a.

Kawamura, K., Sempere, R., Imai, Y., Fujii, Y., and Hayashi, M.: Water soluble dicarboxylic acids and related compounds in Antarctic aerosols, J. Geophys. Res.-Atmos., 101, 18721-18728, 1996b.

Kawamura, K., Imai, Y., and Barrie, L. A.: Photochemical production and loss of organic acids in high Arctic aerosols during longrange transport and polar sunrise ozone depletion events, Atmos. Environ., 39, 599-614, 2005.

Kerminen, V. M., Teinila, K., Hillamo, R., and Makela, T.: Sizesegregated chemistry of particulate dicarboxylic acids in the Arctic atmosphere, Atmos. Environ., 33, 2089-2100, 1999.

Kerminen, V. M., Ojanen, C., Pakkanen, T., Hillamo, R., Aurela, M., and Merilainen, J.: Low-molecular-weight dicarboxylic acids in an urban and rural atmosphere, J. Aerosol Sci., 31, 349-362, 2000 .

Kerminen, V. M., Hillamo, R., Teinila, K., Pakkanen, T., Allegrini, I., and Sparapani, R.: Ion balances of size-resolved tropospheric aerosol samples: Implications for the acidity and atmospheric processing of aerosols, Atmos. Environ., 35, 5255-5265, 2001.

Khalil, M. A. K. and Rasmussen, R. A.: Tracers of wood smoke, Atmos. Environ., 37, 1211-1222, doi:10.1016/s13522310(02)01014-2, 2003.

Kleefeld, S., Hoffer, A., Krivácsy, Z., and Jennings, S. G.: Importance of organic and black carbon in atmospheric aerosols at Mace Head, on the West Coast of Ireland $\left(53^{\circ} 19^{\prime} \mathrm{N}, 9^{\circ} 54^{\prime} \mathrm{W}\right)$, Atmos. Environ., 36, 4479-4490, 2002.

Kourtchev, I., Warnke, J., Maenhaut, W., Hoffmann, T., and Claeys, M.: Polar organic marker compounds in $\mathrm{PM}_{2.5}$ aerosol from a mixed forest site in western Germany, Chemosphere, 73, 13081314, doi:10.1016/j.chemosphere.2008.07.011, 2008.

Kourtchev, I., Copolovici, L., Claeys, M., and Maenhaut, W.: Characterization of Atmospheric Aerosols at a Forested Site in Central Europe, Environ. Sci. Technol., 43, 4665-4671, doi:10.1021/es803055w, 2009. 
Pradeep Kumar, P., Broekhuizen, K., and Abbatt, J. P. D.: Organic acids as cloud condensation nuclei: Laboratory studies of highly soluble and insoluble species, Atmos. Chem. Phys., 3, 509-520, doi:10.5194/acp-3-509-2003, 2003.

Kundu, S., Kawamura, K., Andreae, T. W., Hoffer, A., and Andreae, M. O.: Molecular distributions of dicarboxylic acids, ketocarboxylic acids and $\alpha$-dicarbonyls in biomass burning aerosols: implications for photochemical production and degradation in smoke layers, Atmos. Chem. Phys., 10, 2209-2225, doi:10.5194/acp-10-2209-2010, 2010.

Lan, Z.-J., Chen, D.-L., Li, X., Huang, X.-F., He, L.-Y., Deng, Y.G., Feng, N., and Hu, M.: Modal characteristics of carbonaceous aerosol size distribution in an urban atmosphere of South China, Atmos. Res., 100, 51-60, doi:10.1016/j.atmosres.2010.12.022, 2011.

Legrand, M., Preunkert, S., Oliveira, T., Pio, C. A., Hammer, S., Gelencsér, A., Kasper-Giebl, A., and Laj, P.: Origin of C-2-C-5 dicarboxylic acids in the European atmosphere inferred from yearround aerosol study conducted at a west-east transect, J. Geophys. Res.-Atmos., 112, D23s07, doi:10.1029/2006jd008019, 2007.

Lim, H. J., Carlton, A. G., and Turpin, B. J.: Isoprene forms secondary organic aerosol through cloud processing: Model simulations, Environ. Sci. Technol., 39, 4441-4446, doi:10.1021/Es048039h, 2005.

Limbeck, A., Kraxner, Y., and Puxbaum, H.: Gas to particle distribution of low molecular weight dicarboxylic acids at two different sites in central Europe (Austria), J. Aerosol Sci., 36, 9911005, 2005.

Liu, S., Day, D. A., Shields, J. E., and Russell, L. M.: Ozone-driven daytime formation of secondary organic aerosol containing carboxylic acid groups and alkane groups, Atmos. Chem. Phys., 11, 8321-8341, doi:10.5194/acp-11-8321-2011, 2011.

Maenhaut, W., Wang, W., and Chi, X. G.: Semivolatile behaviour and filter sampling artifacts for dicarboxylic acids during summer campaigns at three forested sites in Europe, Boreal Environ. Res., 16, 273-287, 2011.

Matsumoto, K., Nagao, I., Tanaka, H., Miyaji, H., Iida, T., and Ikebe, Y.: Seasonal characteristics of organic and inorganic species and their size distributions in atmospheric aerosols over the northwest Pacific Ocean, Atmos. Environ., 32, 1931-1946, 1998.

Meng, Z. Y. and Seinfeld, J. H.: On the Source of the Submicrometer Droplet Mode of Urban and Regional Aerosols, Aerosol Sci. Tech., 20, 253-265, 1994.

Mészáros, E., Barcza, T., Gelencsér, A., Hlavay, J., Kiss, G., Krivácsy, Z., Molnar, A., and Polyak, K.: Size distributions of inorganic and organic species in the atmospheric aerosol in Hungary, J. Aerosol Sci., 28, 1163-1175, 1997.

Miyazaki, Y., Aggarwal, S. G., Singh, K., Gupta, P. K., and Kawamura, K.: Dicarboxylic acids and water-soluble organic carbon in aerosols in New Delhi, India, in winter: Characteristics and formation processes, J. Geophys. Res.-Atmos., 114, D19206, doi:10.1029/2009jd011790, 2009.

Miyazaki, Y., Kawamura, K., and Sawano, M.: Size distributions and chemical characterization of water-soluble organic aerosols over the western North Pacific in summer, J. Geophys. Res.Atmos., 115, D23210, doi:10.1029/2010jd014439, 2010.
Mochida, M., Kawabata, A., Kawamura, K., Hatsushika, H., and Yamazaki, K.: Seasonal variation and origins of dicarboxylic acids in the marine atmosphere over the western North Pacific, J. Geophys. Res.-Atmos., 108, 4193, doi:10.1029/2002jd002355, 2003a.

Mochida, M., Umemoto, N., Kawamura, K., and Uematsu, M.: Bimodal size distribution of C-2-C-4 dicarboxylic acids in the marine aerosols, Geophys. Res. Lett., 30, 1672, doi:10.1029/2003gl017451, 2003b.

Müller, K., van Pinxteren, D., Plewka, A., Svrcina, B., Kramberger, H., Hofmann, D., Bächmann, K., and Herrmann, H.: Aerosol characterisation at the FEBUKO upwind station Goldlauter (II): Detailed organic chemical characterisation, Atmos. Environ., 39, 4219-4231, 2005.

Myriokefalitakis, S., Tsigaridis, K., Mihalopoulos, N., Sciare, J., Nenes, A., Kawamura, K., Segers, A., and Kanakidou, M.: Incloud oxalate formation in the global troposphere: a 3-D modeling study, Atmos. Chem. Phys., 11, 5761-5782, doi:10.5194/acp11-5761-2011, 2011.

Narukawa, M., Kawamura, K., Takeuchi, N., and Nakajima, T.: Distribution of dicarboxylic acids and carbon isotopic compositions in aerosols from 1997 Indonesian forest fires, Geophys. Res. Lett., 26, 3101-3104, 1999.

Narukawa, M., Kawamura, K., Anlauf, K. G., and Barrie, L. A.: Fine and coarse modes of dicarboxylic acids in the Arctic aerosols collected during the Polar Sunrise Experiment 1997, J. Geophys. Res.-Atmos., 108, 4575, doi:10.1029/2003jd003646, 2003a.

Narukawa, M., Kawamura, K., Okada, K., Zaizen, Y., and Makino, Y.: Aircraft measurement of dicarboxylic acids in the free tropospheric aerosols over the western to central North Pacific, Tellus, 55, 777-786, 2003b.

Neusüß, C., Pelzing, M., Plewka, A., and Herrmann, H.: A new analytical approach for size-resolved speciation of organic compounds in atmospheric aerosol particles: Methods and first results, J. Geophys. Res.-Atmos., 105, 4513-4527, 2000.

Neusüß, C., Wex, H., Birmili, W., Wiedensohler, A., Koziar, C., Busch, B., Brüggemann, E., Gnauk, T., Ebert, M., and Covert, D. S.: Characterization and parameterization of atmospheric particle number-, mass-, and chemical-size distributions in central Europe during LACE 98 and MINT, J. Geophys. Res.-Atmos., 107, 8127, doi:10.1029/2001JD000514, 2002.

Oliveira, C., Pio, C., Alves, C., Evtyugina, M., Santos, P., Gonçalves, V., Nunes, T., Silvestre, A. J. D., Palmgren, F., Wåhlin, P., and Harrad, S.: Seasonal distribution of polar organic compounds in the urban atmosphere of two large cities from the North and South of Europe, Atmos. Environ., 41, 5555-5570, doi:10.1016/j.atmosenv.2007.03.001, 2007.

Orzechowska, G. E. and Paulson, S. E.: Photochemical sources of organic acids. 1. Reaction of ozone with isoprene, propene, and 2-butenes under dry and humid conditions using SPME, J. Phys. Chem. A, 109, 5358-5365, 2005.

Plewka, A., Gnauk, T., Brüggemann, E., Neusüß, C., and Herrmann, H.: Size-resolved aerosol characterization for a polluted episode at the IfT research station Melpitz in autumn 1997, J. Atmos. Chem., 48, 131-156, 2004.

Prenni, A. J., De Mott, P. J., and Kreidenweis, S. M.: Water uptake of internally mixed particles containing ammonium sulfate and dicarboxylic acids, Atmos. Environ., 37, 4243-4251, 2003. 
Rinaldi, M., Decesari, S., Carbone, C., Finessi, E., Fuzzi, S., Ceburnis, D., O’Dowd, C. D., Sciare, J., Burrows, J. P., Vrekoussis, M., Ervens, B., Tsigaridis, K., and Facchini, M. C.: Evidence of a natural marine source of oxalic acid and a possible link to glyoxal, J. Geophys. Res.-Atmos., 116, D16204, doi:10.1029/2011jd015659, 2011.

Rogge, W. F., Hildemann, L. M., Mazurek, M. A., Cass, G. R., and Simoneit, B. R. T.: Sources of fine organic aerosol. 1. Charbroilers and meat cooking operations, Environ. Sci. Technol., 25, 1112-1125, 1991.

Rogge, W. F., Hildemann, L. M., Mazurek, M. A., Cass, G. R., and Simoneit, B. R. T.: Sources of fine organic aerosol. 2. Noncatalyst and catalyst- equipped automobiles and heavy-duty diesel trucks, Environ. Sci. Technol., 27, 636-651, 1993a.

Rogge, W. F., Mazurek, M. A., Hildemann, L. M., Cass, G. R., and Simoneit, B. R. T.: Quantification of urban organic aerosols at a molecular level: Identification, abundance and seasonal variation, Atmos. Environ. A-Gen., 27, 1309-1330, 1993 b.

Rogge, W. F., Hildemann, L. M., Mazurek, M. A., Cass, G. R., and Simoneit, B. R. T.: Sources of fine organic aerosol. 6. Cigarette smoke in the urban atmosphere, Environ. Sci. Technol., 28, 1375-1388, 1994.

Röhrl, A., and Lammel, G.: Dicarboxylic acids in atmospheric aerosols: Local or regional formation?, J. Aerosol Sci., 31, S348S349, 2000.

Röhrl, A. and Lammel, G.: Low molecular weight dicarboxylic acids and glyoxylic acid: Seasonal and air mass characteristics, Environ. Sci. Technol., 35, 95-101, 2001.

Röhrl, A. and Lammel, G.: Determination of malic acid and other C-4 dicarboxylic acids in atmospheric aerosol samples, Chemosphere, 46, 1195-1199, 2002.

Saarikoski, S., Carbone, S., Decesari, S., Giulianelli, L., Angelini, F., Canagaratna, M., Ng, N. L., Trimborn, A., Facchini, M. C., Fuzzi, S., Hillamo, R., and Worsnop, D.: Chemical characterization of springtime submicrometer aerosol in Po Valley, Italy, Atmos. Chem. Phys., 12, 8401-8421, doi:10.5194/acp-12-84012012, 2012.

Samy, S. and Zielinska, B.: Secondary organic aerosol production from modern diesel engine emissions, Atmos. Chem. Phys., 10, 609-625, doi:10.5194/acp-10-609-2010, 2010.

Sato, K., Hatakeyama, S., and Imamura, T.: Secondary organic aerosol formation during the photooxidation of toluene: $\mathrm{NO}_{\mathrm{x}}$ dependence of chemical composition, J. Phys. Chem. A, 111, 9796-9808, doi:10.1021/Jp071419f, 2007.

Satsumabayashi, H., Kurita, H., Yokouchi, Y., and Ueda, H.: Photochemical formation of particulate dicarboxylic acids under longrange transport in central Japan, Atmos. Environ. A-Gen., 24, 1443-1450, 1990.

Scheinhardt, S., Müller, K., Spindler, G., and Herrmann, H.: Complexation of trace metals in size-segregated aerosol particles at nine sites in Germany, Atmos. Environ., 74, 102-109, doi:10.1016/j.atmosenv.2013.03.023, 2013.

Sorooshian, A., Varutbangkul, V., Brechtel, F. J., Ervens, B., Feingold, G., Bahreini, R., Murphy, S. M., Holloway, J. S., Atlas, E. L., Buzorius, G., Jonsson, H., Flagan, R. C., and Seinfeld, J. H.: Oxalic acid in clear and cloudy atmospheres: Analysis of data from International Consortium for Atmospheric Research on Transport and Transformation 2004, J. Geophys. Res.-Atmos., 111, D23s45, doi:10.1029/2005jd006880, 2006.
Sorooshian, A., Ng, N. L., Chan, A. W. H., Feingold, G., Flagan, R. C., and Seinfeld, J. H.: Particulate organic acids and overall water-soluble aerosol composition measurements from the 2006 Gulf of Mexico Atmospheric Composition and Climate Study (GoMACCS), J. Geophys. Res.-Atmos., 112, D13201, doi:10.1029/2007jd008537, 2007.

Sorooshian, A., Murphy, S. M., Hersey, S., Bahreini, R., Jonsson, H., Flagan, R. C., and Seinfeld, J. H.: Constraining the contribution of organic acids and AMS $m / z, 44$ to the organic aerosol budget: On the importance of meteorology, aerosol hygroscopicity, and region, Geophys. Res. Lett., 37, L21807, doi:10.1029/2010g1044951, 2010.

Stone, E. A., Hedman, C. J., Zhou, J. B., Mieritz, M., and Schauer, J. $\mathrm{J} .:$ Insights into the nature of secondary organic aerosol in Mexico City during the MILAGRO experiment 2006, Atmos. Environ., 44, 312-319, doi:10.1016/j.atmosenv.2009.10.036, 2010.

Tedetti, M., Kawamura, K., Charriere, B., Chevalier, N., and Sempere, R.: Determination of low molecular weight dicarboxylic and ketocarboxylic acids in seawater samples, Anal. Chem., 78, 6012-6018, doi:10.1021/Ac052226w, 2006.

Tilgner, A. and Herrmann, H.: Radical-driven carbonyl-to-acid conversion and acid degradation in tropospheric aqueous systems studied by CAPRAM, Atmos. Environ., 44, 5415-5422, doi:10.1016/j.atmosenv.2010.07.050, 2010.

Turekian, V. C., Macko, S. A., and Keene, W. C.: Concentrations, isotopic compositions, and sources of size-resolved, particulate organic carbon and oxalate in near-surface marine air at Bermuda during spring, J. Geophys. Res.-Atmos., 108, 4157, doi:10.1029/2002jd002053, 2003.

van Pinxteren, D., Plewka, A., Hofmann, D., Müller, K., Kramberger, H., Svrcina, B., Bächmann, K., Jaeschke, W., Mertes, S., Collett, J. L., and Herrmann, H.: Schmücke hill cap cloud and valley stations aerosol characterisation during FEBUKO (II): Organic compounds, Atmos. Environ., 39, 4305-4320, 2005.

van Pinxteren, D., Brüggemann, E., Gnauk, T., Iinuma, Y., Müller, K., Nowak, A., Achtert, P., Wiedensohler, A., and Herrmann, H.: Size- and time-resolved chemical particle characterization during CAREBeijing-2006: Different pollution regimes and diurnal profiles, J. Geophys. Res.-Atmos., 114, D00g09, doi:10.1029/2008jd010890, 2009.

van Pinxteren, D., Brüggemann, E., Gnauk, T., Müller, K., Thiel, C., and Herrmann, H.: A GIS based approach to back trajectory analysis for the source apportionment of aerosol constituents and its first application, J. Atmos. Chem., 67, 1-28, doi:10.1007/s10874-011-9199-9, 2010.

Veres, P. R., Roberts, J. M., Cochran, A. K., Gilman, J. B., Kuster, W. C., Holloway, J. S., Graus, M., Flynn, J., Lefer, B., Warneke, C., and de Gouw, J.: Evidence of rapid production of organic acids in an urban air mass, Geophys. Res. Lett., 38, L17807, doi:10.1029/2011g1048420, 2011.

Wang, H. B. and Shooter, D.: Low molecular weight dicarboxylic acids in $\mathrm{PM}_{10}$ a city with intensive solid fuel burning, Chemosphere, 56, 725-733, 2004.

Warneck, P.: In-cloud chemistry opens pathway to the formation of oxalic acid in the marine atmosphere, Atmos. Environ., 37, 2423-2427, 2003.

Weber, R. J., Sullivan, A. P., Peltier, R. E., Russell, A., Yan, B., Zheng, M., de Gouw, J., Warneke, C., Brock, C., Holloway, J. S., Atlas, E. L., and Edgerton, E.: A study of secondary or- 
ganic aerosol formation in the anthropogenic-influenced southeastern United States, J. Geophys. Res.-Atmos., 112, D13302, doi:10.1029/2007jd008408, 2007.

Worton, D. R., Goldstein, A. H., Farmer, D. K., Docherty, K. S., Jimenez, J. L., Gilman, J. B., Kuster, W. C., de Gouw, J., Williams, B. J., Kreisberg, N. M., Hering, S. V., Bench, G., McKay, M., Kristensen, K., Glasius, M., Surratt, J. D., and Seinfeld, J. H.: Origins and composition of fine atmospheric carbonaceous aerosol in the Sierra Nevada Mountains, California, Atmos. Chem. Phys., 11, 10219-10241, doi:10.5194/acp-1110219-2011, 2011.

Yang, L. M. and Yu, L. E.: Measurements of Oxalic Acid, Oxalates, Malonic Acid, and Malonates in Atmospheric Particulates, Environ. Sci. Technol., 42, 9268-9275, doi:10.1021/Es801820z, 2008.

Yao, X. H., Chan, C. K., Fang, M., Cadle, S., Chan, T., Mulawa, P., He, K. B., and Ye, B. M.: The water-soluble ionic composition of $\mathrm{PM}_{2.5}$ in Shanghai and Beijing, China, Atmos. Environ., 36, 4223-4234, 2002.
Yao, X. H., Lau, A. P. S., Fang, M., Chan, C. K., and Hu, M.: Size distributions and formation of ionic species in atmospheric particulate pollutants in Beijing, China: 2 - dicarboxylic acids, Atmos. Environ., 37, 3001-3007, 2003.

Yu, J. Z., Huang, X. F., Xu, J. H., and Hu, M.: When aerosol sulfate goes up, so does oxalate: Implication for the formation mechanisms of oxalate, Environ. Sci. Technol., 39, 128-133, 2005.

Zobrist, B., Marcolli, C., Koop, T., Luo, B. P., Murphy, D. M., Lohmann, U., Zardini, A. A., Krieger, U. K., Corti, T., Cziczo, D. J., Fueglistaler, S., Hudson, P. K., Thomson, D. S., and Peter, T.: Oxalic acid as a heterogeneous ice nucleus in the upper troposphere and its indirect aerosol effect, Atmos. Chem. Phys., 6, 3115-3129, doi:10.5194/acp-6-3115-2006, 2006. 